\title{
Emissions of primary aerosol and precursor gases in the years 2000 and 1750 prescribed data-sets for AeroCom
}

\author{
F. Dentener ${ }^{1}$, S. Kinne ${ }^{2}$, T. Bond ${ }^{3}$, O. Boucher ${ }^{4}$, J. Cofala ${ }^{5}$, S. Generoso ${ }^{6}$, P. Ginoux ${ }^{7}$, S. Gong ${ }^{8}$, J. J. Hoelzemann ${ }^{2}$,

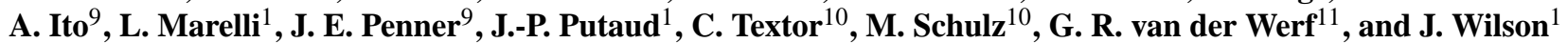 \\ ${ }^{1}$ European Commission, Institute for Environment and Sustainability, Ispra, Italy \\ ${ }^{2}$ MPI Hamburg, Germany \\ ${ }^{3}$ Univ. of Illinois-Champagne, USA \\ ${ }^{4}$ Met Office, Exeter, UK \\ ${ }^{5}$ IIASA Laxenburg, Austria \\ ${ }^{6}$ EPFL-ENAC, Lausanne, Switzerland \\ ${ }^{7}$ NOAA-GFDL Princeton, USA \\ ${ }^{8}$ ARQM Met Service Toronto, Canada \\ ${ }^{9}$ Univ. of Michigan Ann Arbor, USA \\ ${ }^{10}$ LSCE Saclay, France \\ ${ }^{11}$ Vrije Universiteit Amsterdam, The Netherlands
}

Received: 28 November 2005 - Published in Atmos. Chem. Phys. Discuss.: 7 April 2006

Revised: 31 July 2006 - Accepted: 16 August 2006 - Published: 26 September 2006

\begin{abstract}
Inventories for global aerosol and aerosol precursor emissions have been collected (based on published inventories and published simulations), assessed and prepared for the year 2000 (present-day conditions) and for the year 1750 (pre-industrial conditions). These global datasets establish a comprehensive source for emission input to global modeling, when simulating the aerosol impact on climate with state-of-the-art aerosol component modules. As these modules stratify aerosol into dust, sea-salt, sulfate, organic matter and soot, for all these aerosol types global fields on emission strength and recommendations for injection altitude and particulate size are provided. Temporal resolution varies between daily (dust and sea-salt), monthly (wild-land fires) and annual (all other emissions). These datasets benchmark aerosol emissions according to the knowledge in the year 2004. They are intended to serve as systematic constraints in sensitivity studies of the AeroCom initiative, which seeks to quantify (actual) uncertainties in aerosol global modeling.
\end{abstract}

\section{Introduction}

Aerosol introduces large uncertainties in climate modeling (IPCC, 2001). These uncertainties are fueled by limitations to adequately represent aerosol amount, aerosol properties

Correspondence to: S. Kinne

(stefan.kinne@zmaw.de) and aerosol interactions (e.g. the aerosol impact on cloud properties) in global modeling. In 2003 the Aerosol Inter Comparison project AeroCom (http://nansen.ipsl.jussieu.fr/ AEROCOM/) has been initiated to identify the specific nature of these uncertainties. Detailed output (of aerosol modules) of more than 15 global models was systematically analyzed, mainly by comparing to available data from in-situ sampling and remote sensing. In initial comparisons of the AeroCom Experiment "A" modelers were allowed to use aerosol emissions (an essential model input) of their choice, without a clear connection to any particular year. This complicated the interpretation of model diversity (Kinne et al., 2005; Textor et al., 2005). It remained unclear, if unusual model-tendencies for any particular aerosol component related to model input (e.g. emission-data) or to aerosol processing and transport. In an effort to harmonize aerosol input, two additional AeroCom simulations were requested with prescribed emission data for primary aerosol and for aerosol precursor gases. AeroCom Experiment "B" ties model input (e.g. aerosol emissions and meteorological data via nudging in GCMs) to the year 2000 in an effort to evaluate models with observational data available for that year. AeroCom Experiment "Pre" was designed to establish a pre-industrial (year 1750) modeling reference, to extract the anthropogenic aerosol impact in conjunction with Experiment "B" (Schulz et al., 2006). For both Experiments "B" and "Pre" global data sets for aerosol emissions needed to be defined. For year 2000 emissions (Experiment "B"), recently published

Published by Copernicus GmbH on behalf of the European Geosciences Union. 
Table 1. AeroCom common (natural) emissions.

\begin{tabular}{|c|c|c|c|c|c|c|c|c|}
\hline & $\begin{array}{l}\text { time } \\
\text { resolution }\end{array}$ & $\begin{array}{l}\text { aero } \\
\text { type* }\end{array}$ & $\begin{array}{l}\text { injection } \\
\text { altitude }\end{array}$ & $\mathrm{r}_{m}[\mu \mathrm{m}]$ & $\sigma$ & $\begin{array}{l}\mathrm{r}_{\mathrm{eff}} \\
{[\mu \mathrm{m}]}\end{array}$ & $\begin{array}{l}\text { flux[Tg/yr] } \\
\text { AeroCom }\end{array}$ & $\begin{array}{l}\text { flux }[\mathrm{Tg} / \mathrm{yr}] \\
\text { IPCC-TAR }\end{array}$ \\
\hline dust & daily & $\mathrm{DU}$ & surface & $0.650^{C}$ & $2.0^{C}$ & 2.10 & 1678 & $2150 \pm 50 \%$ \\
\hline sea-salt & daily & SS & surface & $0.740^{C}$ & $2.0^{C}$ & 2.50 & 7925 & $3340 \pm 80 \%$ \\
\hline DMS & daily & $S$ & surface & 0.040 & 1.8 & 0.095 & 18.2 & $25 \pm 60 \%$ \\
\hline volcanic, explosive & yearly & $\mathrm{S}^{+}$ & $\begin{array}{l}\left(\mathrm{V}_{T}+500 \mathrm{~m}\right)- \\
\left(\mathrm{V}_{T}+1500 \mathrm{~m}\right)\end{array}$ & $\begin{array}{l}0.040^{M} \\
0.015^{M}\end{array}$ & 1.8 & 0.059 & 2.0 & \\
\hline volcanic, continuous & yearly & $\mathrm{S}^{+}$ & $\begin{array}{l}\left(0.67 * \mathrm{~V}_{T}\right)- \\
\left(1.0 * \mathrm{~V}_{T}\right)\end{array}$ & $\begin{array}{l}0.040^{M} \\
0.015^{M}\end{array}$ & 1.8 & 0.059 & 12.6 & $\begin{array}{l}9.3[4-20] \\
\text { expl. + cont. }\end{array}$ \\
\hline SOA & monthly & POM & surface & & & & 19.1 & {$[12-70]^{K}$} \\
\hline
\end{tabular}

* DU-dust, SS-sea-salt, S-sulfur $\left[\mathrm{m}(\mathrm{S})=0.5 * \mathrm{~m}\left(\mathrm{SO}_{2}\right.\right.$ ) or $\left.\mathrm{m}(\mathrm{S})=0.33 * \mathrm{~m}\left(\mathrm{SO}_{4}\right)\right]$, POM-particulate organic matter [=1.40*organic carbon]

$+2.5 \%$ of sulfur should be emitted as particulate $\mathrm{SO}_{4}$, most sulfur (S) is emitted as gaseous $\mathrm{SO}_{2}$

${ }^{C}$ log-normal size-distribution parameters (number mode radius and standard dev.) of the coarse size mode

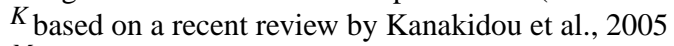

${ }^{M} 50 \%$ of the volcanic mass each is associated with a smaller $(.015 \mu \mathrm{m})$ and larger $(.040 \mu \mathrm{m})$ number mode radius. $\mathrm{V}_{T}$ indicates the altitude of the top of the volcano.

emission inventories (e.g. Bond et al., 2004; van der Werf et al., 2003) and recently published model simulations (e.g. Gong et al., 2003; Ginoux et al., 2003; Boucher et al., 2003) were interpreted and combined to a comprehensive dataset addressing all major aerosol emission sources. For preindustrial emissions (Experiment "Pre"), year 2000 emissions of non-natural origin were scaled back according to changes in population, crop production and wood consumption, whereas natural emissions (e.g. dust, sea-salt) remained at year 2000 levels. Background and details to both recommended data-sets are now introduced.

\section{General features and overview}

For the years 1750 and 2000, global aerosol emission fields are defined at a common spatial resolution of $1.0^{\circ}$ [latitude] $* 1.0^{\circ}$ [longitude]. Emission fluxes for all relevant aerosol species and precursors in global modeling are provided in units of $\mathrm{kg}$ per $\left(1.0^{\circ} * 1.0^{\circ}\right)$ grid-box. Temporal resolution ranges from daily to yearly depending on the species. In addition, injection heights and sizes of particulate emissions are prescribed. Emissions are categorized by their origin as either 'natural' or "anthropogenically modified".

Natural emissions such as dust, sea-salt, oceanic DMS and volcanic sources are assumed to be identical in both Experiment "B" (year 2000) and Experiment "Pre" (year 1750). Thus, these emissions are referred to as "common emissions". They are introduced in Sect. 3. "Anthropogenically modified emissions" as they changed with industrialization are presented separately. Those referring to the year 2000 (for Experiment "B") are described in Sect. 4 and those re- ferring to the year 1750 (for Experiment "Pre") are explained in Sect. 5. The temporal resolution of all data-sets is summarized in Sect. 6. Emission injection heights, in particular those for wild-land fires are explained in Sect. 7. And size recommendations are addressed in Sect. 8. All emission data-sets are available (in netcdf data format) via a dedicated file transfer site at the Joint Research Center (JRC) in Ispra, Italy: ftp://ftp.ei.jrc.it/pub/Aerocom/ or available from the authors of this paper. To help in locating specific data, all ftpsite subdirectories and their content are listed in Appendix A.

\section{Common emissions}

Natural emissions (common to both emission scenarios) include wind-blown contributions of mineral dust (DU) and sea-salt (SS), sulfur (S) contributions from volcanoes and DiMethyl Sulphide (DMS, mainly oceanic) and Secondary Organic Aerosol (SOA) formed from natural Volatile Organic Compound (VOC) emissions. Since in 2004 most models did not include parameterziations for SOA formation, SOA emissions were prescribed to be added to the emissions of Particulate Organic Matter (POM). An overview of recommendations for injection height and particle size and a comparison of annual total fluxes to IPCC-TAR estimates are given in Table 1.

Table 1 also lists size-recommendations in terms of lognormal size-distribution parameters $r_{m}$ (number mode radius) and $\sigma$ (standard deviation), plus the resulting $\mathrm{r}_{\text {eff. This }}$ radiatively most "effective radius" is defined by the ratio of sums by third and second radii moments, $\Sigma r^{3} / \Sigma r^{2}$. Since the effective radius for dust and sea-salt is predominantly 

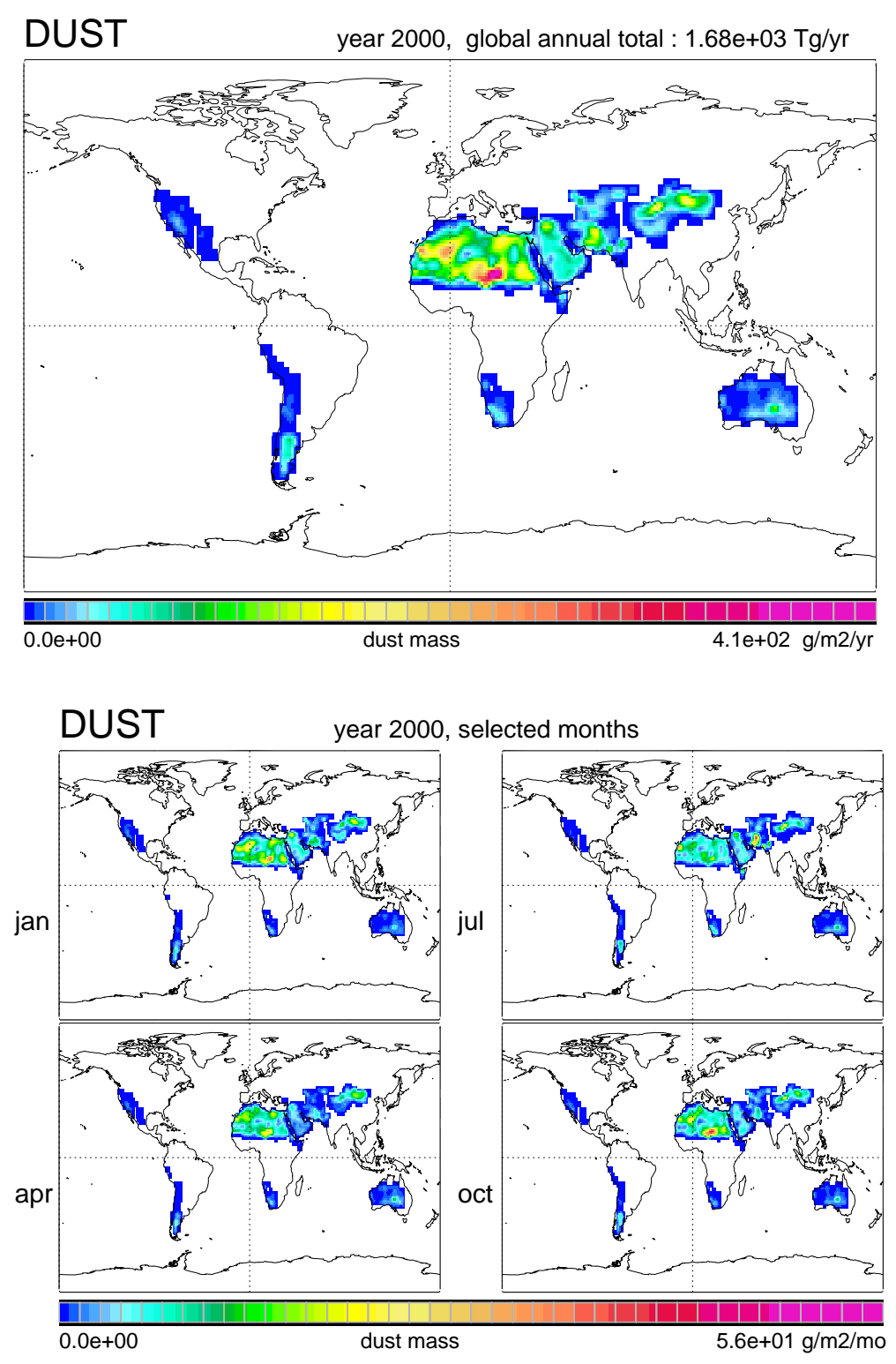

Fig. 1. Global fields of annual dust emission fluxes and dust emissions for four selected months (January, April, July and October). The dust emissions are given in $\mathrm{g} / \mathrm{m}^{2} /$ year or $\mathrm{g} / \mathrm{m}^{2} /$ month according to the linear color scale and its minimum and maximum values.

determined by the coarse mode, only log-normal distribution parameters for the coarse modes are displayed.

The common emissions are evenly distributed over the year unless the emissions are closely tied to near surface winds and their variability. Thus, for dust, sea-salt and DMS a daily temporal resolution was adopted (as a compromise between need and excessively large datasets).

\subsection{Dust}

Emission estimates for dust (DU) are based on simulations with near surface winds of the year 2000 generated by the NASA Goddard Earth Observing System Data Assimilation System (GEOS DAS). The daily average DU flux output was distributed over four size-bins (radii ranges of $0.1-1.0,1.0$ $1.8,1.8-3.0,3.0-6.0 \mu \mathrm{m})$ at $1.0^{\circ}$ [latitude] $* 1.0^{\circ}$ [longitude] horizontal resolution (Ginoux et al., 2001, 2003). To accommodate modal size schemes (frequently used in global modeling) DU flux data (after subdividing the original size-bins each into ten subsections of equal radius-range and number) 

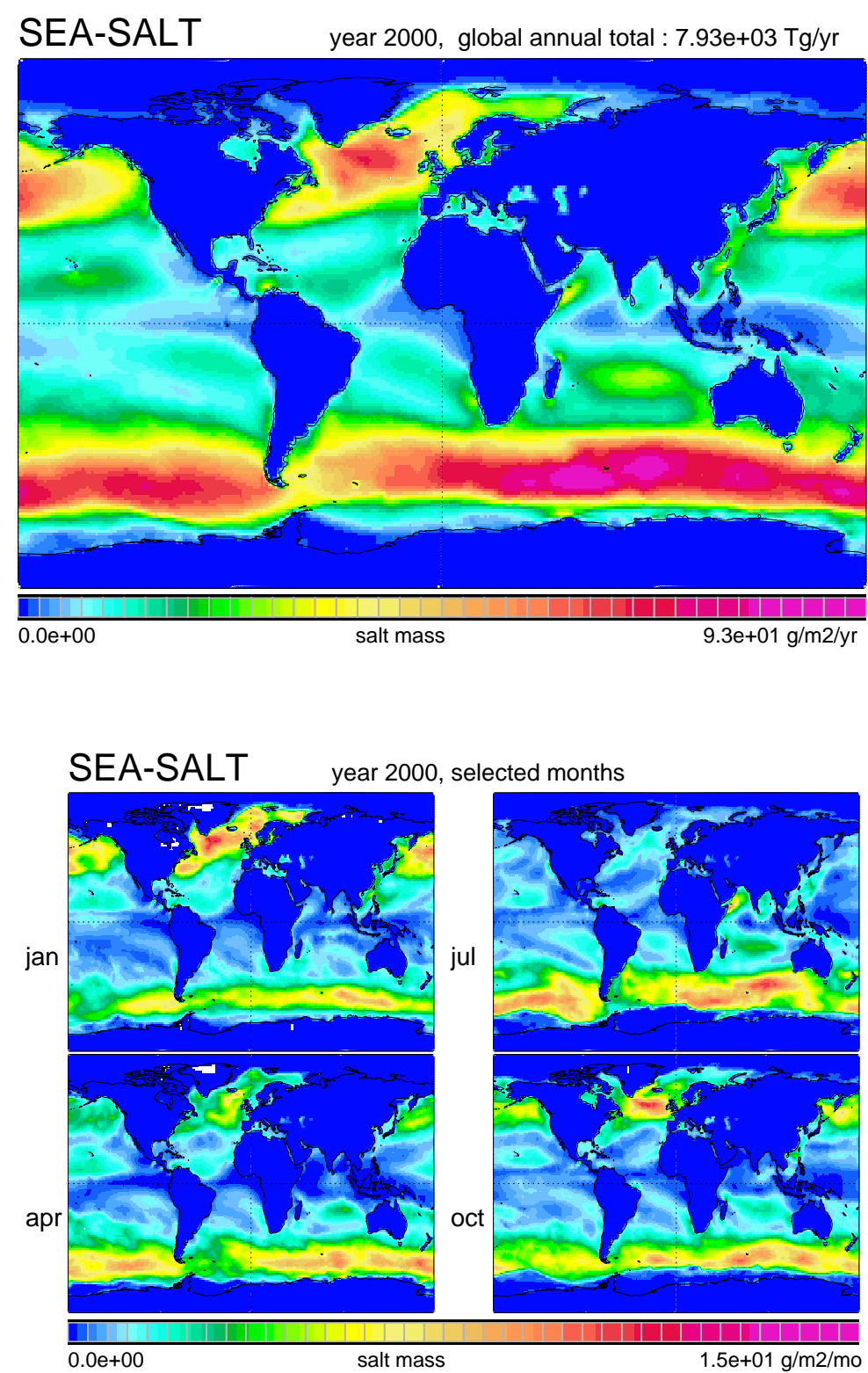

Fig. 2. Global fields of annual sea-salt emission fluxes and sea-salt emissions for four selected months (January, April, July and October). Sea-salt emissions are given in $\mathrm{g} / \mathrm{m}^{2} /$ year or $\mathrm{g} / \mathrm{m}^{2} / \mathrm{month}$ according to the linear color scale and its minimum and maximum values.

were stratified according to size into two domains: accumulation mode (radii: $0.05-0.5 \mu \mathrm{m}$ ) and coarse mode (radii $>0.5 \mu \mathrm{m}$ ). Then for each size domain the DU flux was distributed over a log-normal function, which is defined by the three parameters of mode-radius $r_{m}$ (radius at the peak concentration), standard deviation $\sigma$ (distribution width) and number N. As DU (mass) flux and number concentration in each domain are defined, the mode-radius $r_{m}$ can be determined with assumptions to standard deviation and density.
DU density varies between 2.2 and $2.9 \mathrm{~g} / \mathrm{cm}^{3}$ depending on its mineral composition (e.g. Reid et al., 2003). Thus, assuming an average DU density of $2.5 \mathrm{~g} / \mathrm{cm}^{3}$ and prescribing standard deviations of 1.59 for the accumulation mode and 2.0 for the coarse mode (following assumptions of the M3/M7 size scheme in Wilson et al., 2001), mode-radii $r_{m}$ were determined independently for each mode at each gridpoint and for each time-step. Daily global fields for moderadius and number (along with the prescribed values for 

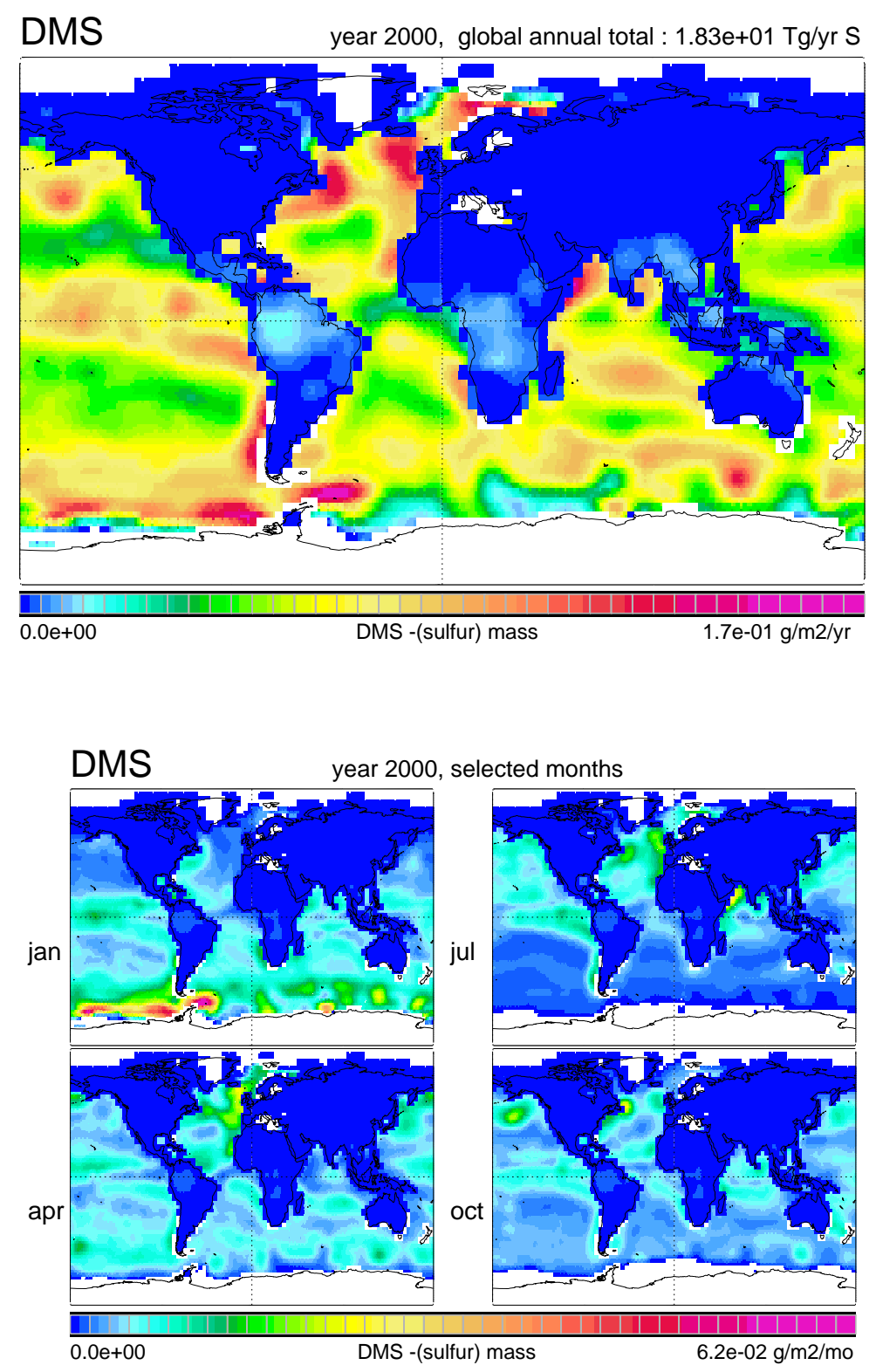

Fig. 3. Global fields of annual DMS flux emissions and DMS emissions for four selected months (January, April, July and October). The DMS emissions are given in $\mathrm{g} / \mathrm{m}^{2} /$ year or $\mathrm{g} / \mathrm{m}^{2} / \mathrm{month}$ according to the linear color scale and its minimum and maximum values.

density and distribution width) establish the recommended emission input for DU in modal size schemes. To accommodate aerosol modules with (size-) bin schemes, software is provided, which can extract the DU emission flux for any DU size-range. Based on the modal approach $98.6 \%$ of the DU flux mass is assigned to the coarse mode (and 1.4\% to accumulation mode). The spatial distributions of DU emissions on an annual and a monthly basis are given in Fig. 1.
The (radiatively) characteristic size of any sizedistribution is commonly represented by the effective radius $\left(r_{\text {eff }}\right)$, defined as the ratio between the sums of third and the second moments of ('equivalent') radii of all individual particles $\left(\Sigma \mathrm{r}^{3} / \Sigma \mathrm{r}^{2}\right)$. The characteristic maximum dimension for DU is about $4 \mu \mathrm{m}$, largely determined by contribution of coarse mode particles (e.g. a coarse mode radius of $0.65 \mu \mathrm{m}$ combined with a standard deviation of 2.0 translates into $2.1 \mu \mathrm{m}$ for $\mathrm{r}_{\text {eff }}$ ). DU emissions are prescribed 

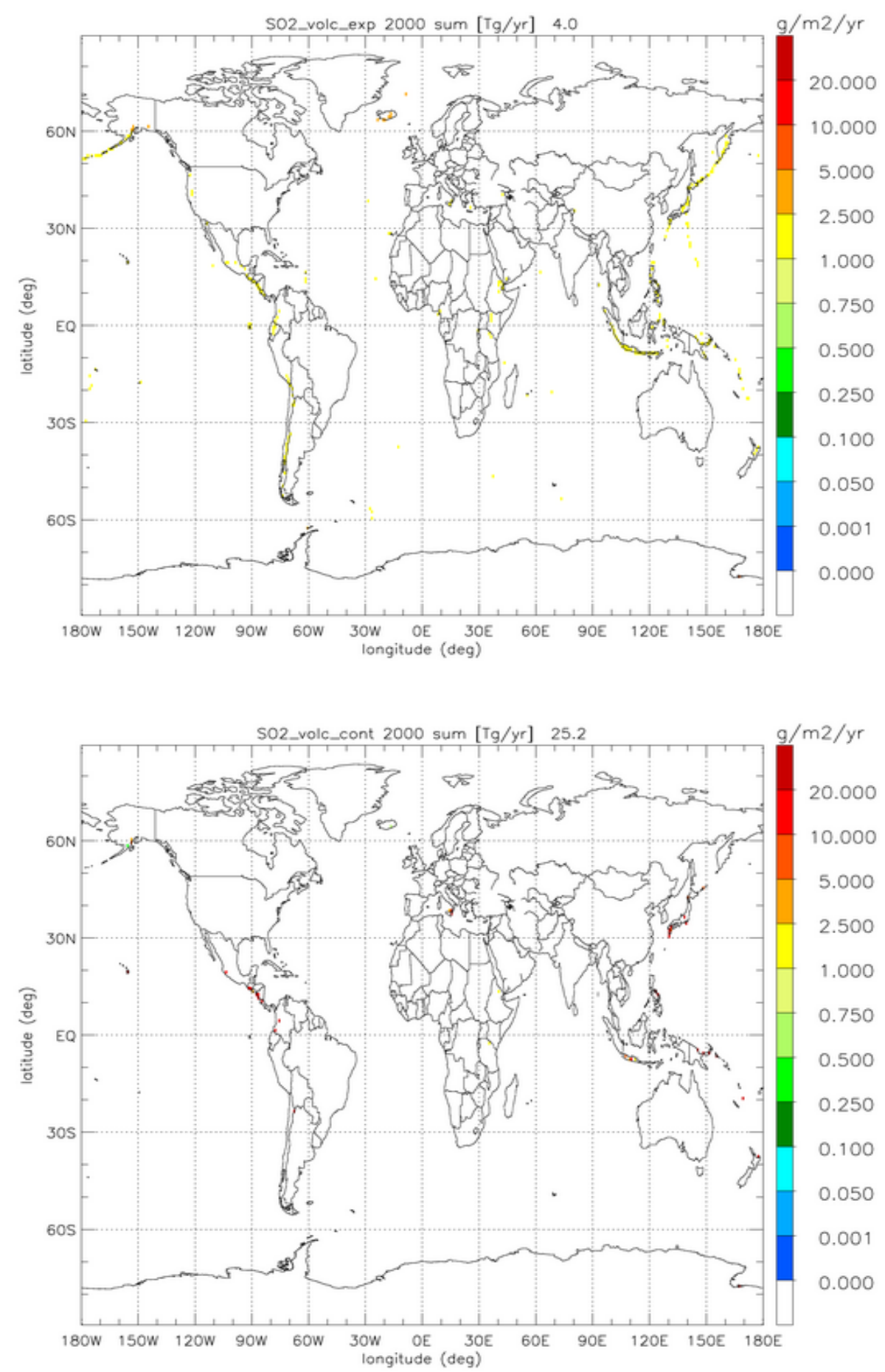

Fig. 4. Annual distribution of volcanic explosive (upper panel) and volcanic continuous $\mathrm{SO}_{2}$ emissions (lower panel).

to take place in the lowest model layer. Biases may have been introduced by limitations of the GEOS DAS meteorology and simplifying assumptions. The coarse (daily) temporal resolution and injections into the lowest model layer only are expected to contribute to DU flux underesti- mates. Inaccuracies are introduced by the simple modal size representation and by model specific implementations (e.g. inconsistencies with boundary layer mixing (e.g. convection) and/or adaptations to different model resolutions). 


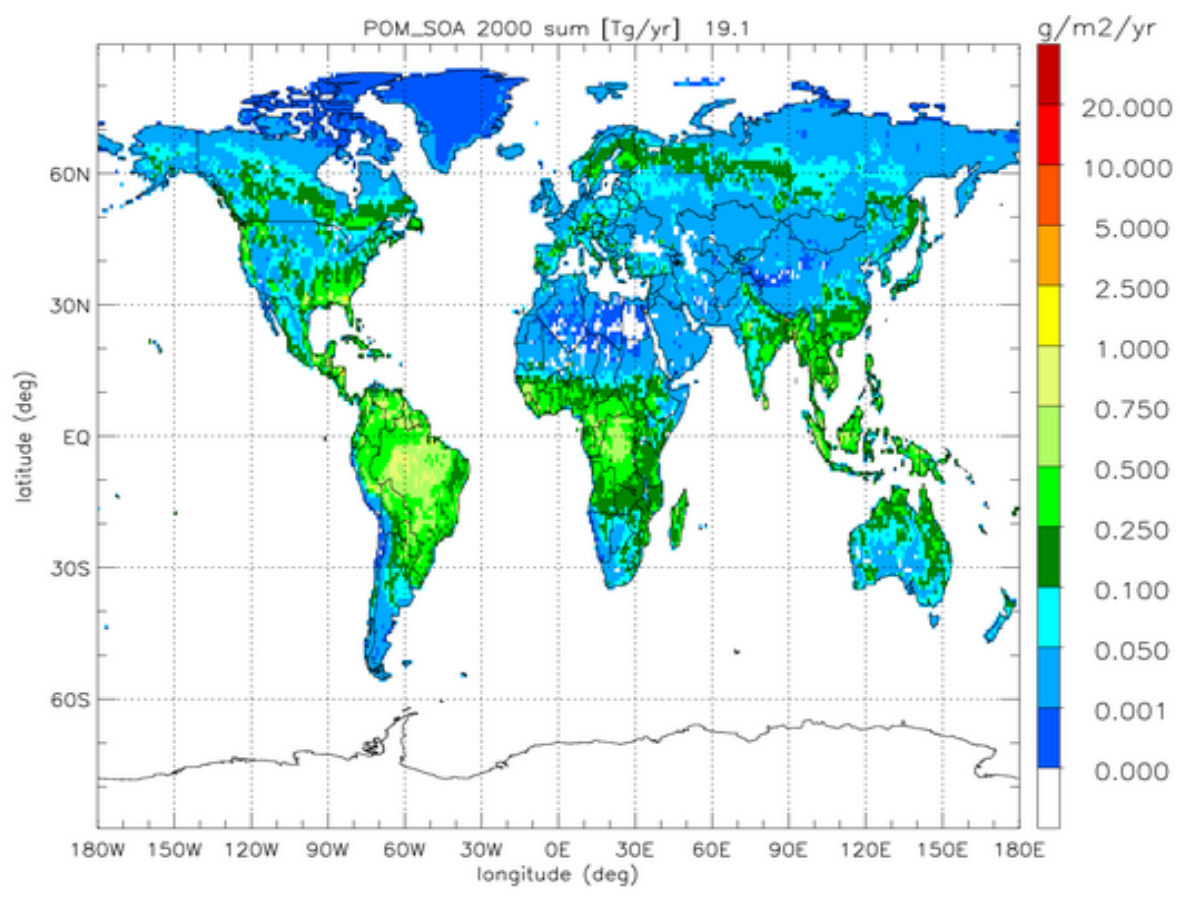

Fig. 5. Annual SOA emissions (tied to natural terpene emissions) for the year 2000.

\subsection{Sea-salt}

Sea-salt (SS) daily emission data are based on year 2000 ECMWF near surface winds. SS mass fluxes are provided over 24 size bins (covering radii from 0.005 to $20.48 \mu \mathrm{m}$ ) at $1.175^{\circ}$ [latitude ${ }^{*} 1.175^{\circ}$ [longitude] horizontal resolution (Gong et al., 2003). Contributions of SS emissions associated with radii larger $10 \mu \mathrm{m}$ were ignored and SS contributions over sea-ice were removed according to monthly ECMWF sea-ice-free-fractions for the year 2000. The data were regridded to a horizontal resolution of $1.0^{\circ} * 1.0^{\circ}$ and redistributed (after subdividing the original size-bins each into ten subsections of equal radius-range and number) over three size domains: Aitken mode (radii $<0.05 \mu \mathrm{m}$ ), accumulation mode (radii: $0.05-0.5 \mu \mathrm{m}$ ) and coarse mode (radii $>0.5 \mu \mathrm{m}$ ). Then for each size domain SS fluxes were distributed over a log-normal function, which is defined by the three parameters of mode-radius $\mathrm{r}_{\mathrm{m}}$, standard deviation $\sigma$ and number N. As SS (dry-mass) flux and number concentration in each domain are defined, the mode-radius $r_{m}$ can be determined with assumptions to standard deviation and density. Assuming a SS (dry-mass) density of $2.2 \mathrm{~g} / \mathrm{cm}^{3}$ (Hänel, 1976) and prescribing standard deviations of 1.59 for the Aitken and the accumulation modes and 2.0 for the coarse mode (following assumptions of the M3/M7 size scheme in Wilson et al., 2001), mode-radii $r_{m}$ were determined independently for each mode at each grid-point and for each timestep. Daily global fields for mode-radius and number (along with the prescribed values for density and distribution width) establish the recommended emission input for SS in modal size schemes. To accommodate aerosol modules with (size-) bin schemes, software is provided, which extracts SS flux emissions within any size-range. Distributions of SS emissions are displayed in Fig. 2.

The (radiatively) characteristic size of any sizedistribution is commonly represented by the effective radius $\left(\mathrm{r}_{\mathrm{eff}}\right.$ ), defined as the ratio between the sums of third and the second moments of ("equivalent") radii of all individual particles $\left(\Sigma \mathrm{r}^{3} / \Sigma \mathrm{r}^{2}\right)$. The characteristic SS diameter is about $5 \mu \mathrm{m}$, largely determined by coarse mode particle contributions (e.g. a coarse mode radius of $0.74 \mu \mathrm{m}$ in conjunction with a standard deviation of 2 translates into $2.5 \mu \mathrm{m}$ for $\mathrm{r}_{\text {eff }}$ ). SS emissions are prescribed to take place in the lowest model layer. Uncertainty issues are similar to those for DU, including the numerical spread by the modal representation. For example, even though original SS fluxes of radii larger than $10 \mu \mathrm{m}$ were rejected, the coarse size mode flux fit with a large distribution width (standard deviation of 2.0) will lead to non-negligible SS flux contributions for radii up to $25 \mu \mathrm{m}$.

\subsection{DMS}

Daily DMS emission data are based on six hourly data of simulations with the LMDZ general circulation model LOA (Boucher et al., 2003) at $2.5^{\circ}$ [latitude] $* 3.75^{\circ}$ [longitude] resolution. Oceanic DMS emissions are derived by applying a parameterization for air-sea transfer velocities (Nightingale, 2000) to simulated climatology tied to measurement samples 
Table 2. AeroCom anthropogenically modified (full molecular mass) emissions for the year 2000.

\begin{tabular}{|c|c|c|c|c|c|c|c|c|c|}
\hline type & data source & $\begin{array}{l}\text { time re- } \\
\text { solution }\end{array}$ & aero type & $\begin{array}{l}\text { injection } \\
\text { altitude }\end{array}$ & $\mathrm{r}_{m}[\mu \mathrm{m}]$ & $\sigma$ & $\mathrm{r}_{\mathrm{eff}}[\mu \mathrm{m}]$ & $\begin{array}{l}\text { flux[Tg/yr] } \\
\text { AeroCom }\end{array}$ & $\begin{array}{l}\text { flux [Tg/yr] } \\
\text { IPCC-TAR }\end{array}$ \\
\hline \multirow[t]{3}{*}{ wild-fire } & GFED & monthly & $\mathrm{BC}$ & 6 layers $H$ & 0.040 & 1.8 & 0.095 & 3.1 & 5.7 [5-9] \\
\hline & GFED & monthly & POM & 6 layers ${ }^{H}$ & 0.040 & 1.8 & 0.095 & 34.7 & $54[45-80]$ \\
\hline & GFED & monthly & $\mathrm{S}^{+}$ & 6 layers $H$ & 0.040 & 1.8 & 0.095 & 4.1 & $2.2[1-6]$ \\
\hline \multirow[t]{2}{*}{ biofuel } & SPEW & yearly & $\mathrm{BC}$ & surface & 0.040 & 1.8 & 0.095 & 1.6 & in wild fire \\
\hline & SPEW & yearly & POM & surface & 0.040 & 1.8 & 0.095 & 9.1 & \\
\hline domestic & IIASA & yearly & $\mathrm{S}^{+}$ & surface & 0.015 & 1.8 & 0.036 & 9.6 & $11.4^{B}$ \\
\hline \multirow[t]{2}{*}{ fossilfuel } & SPEW & yearly & $\mathrm{BC}$ & surface & 0.015 & 1.8 & 0.036 & 3.0 & $6.6[6-8]$ \\
\hline & SPEW & yearly & POM & surface & 0.015 & 1.8 & 0.036 & $3.2(+19.1)$ & $28[10-30]^{A}$ \\
\hline roads & IIASA & yearly & $\mathrm{S}^{+}$ & surface & 0.015 & 1.8 & 0.036 & 1.9 & $3.6^{B}$ \\
\hline shipping & EDGAR & yearly & $\mathrm{S}^{+}$ & surface & 0.500 & 2.0 & 1.66 & 7.8 & $7.3^{B}$ \\
\hline off-road & IIASA & yearly & $\mathrm{S}^{+}$ & surface & 0.015 & 1.8 & 0.036 & 1.6 & $1.9^{B}$ \\
\hline industry & IIASA & yearly & $\mathrm{S}^{+}$ & $100-300 \mathrm{~m}$ & 0.500 & 2.0 & 1.66 & $39.2^{I}$ & $67.5^{B}$ \\
\hline power-pl. & IIASA & yearly & $\mathrm{S}^{+}$ & $100-300 \mathrm{~m}$ & 0.500 & 2.0 & 1.66 & 48.4 & $53.6^{B}$ \\
\hline
\end{tabular}

* S-sulfur $\left[\mathrm{m}(\mathrm{S})=0.5 * \mathrm{~m}\left(\mathrm{SO}_{2}\right.\right.$, $)$ or $\left.\mathrm{m}(\mathrm{S})=0.33 * \mathrm{~m}\left(\mathrm{SO}_{4}\right)\right]$, POM-particulate organic matter [=1.40*organic carbon], BC-black carbon

$+2.5 \%$ of sulfur should be emitted as particulate $\mathrm{SO}_{4}$, most sulfur $(\mathrm{S})$ is emitted as gaseous $\mathrm{SO}_{2}$

${ }^{H}$ 0-100 m, 100-500 m, 500-1000 m, 1-2 km, 2-3 km, 3-6 km, assignment according to Table 4

${ }^{A}$ Cooke et al. (Cooke et al., 1999) report a more moderate amount of $10.1 \mathrm{Tg}$ OC-C/yr.

$B$ based on EDGAR3.2 FT2000 (http://www.rivm.nl/edgar) and Olivier et al. (2005).

${ }^{I}$ probably not all industrial sources are included in the IIASA inventory.

(Kettle and Andreae, 2000). Continental DMS emissions of biogenic origin (Pham et al., 1995) are generally much lower. To exclude unrealistic high contributions over coastal land regions (gridboxes with more than 5\% land fraction), values of the nearest completely continental pixel were adopted. Then daily average data were interpolated onto a $1^{\circ} * 1^{\circ}$-grid. Distributions of DMS emissions are given in Fig. 3.

\subsection{Volcanic emissions}

Annual volcanic (sulfur) emissions data, displayed in Fig. 4, consider both continuous degassing and explosive volcanos. Volcanic sulfur is emitted as $97.5 \% \mathrm{SO}_{2}$ and $2.5 \% \mathrm{SO}$. Data are based on the GEIA inventory (http://www.igac.noaa.gov/ newsletter/22/sulfur.php; http://www.geiacenter.org/) (Andres and Kasgnoc, 1998). However, since there are a number of ambiguities which may lead to implementation differences, an interpreted and updated dataset is provided, which is summarized next.

Data on explosive emissions are based on observational evidence including the Aerosol Index (AI) of TOMS satellite sensors. The multi-annual total emission (at $2 \mathrm{TgS} /$ year) of explosive emissions is equally distributed over all grid boxes with volcanoes that had been active over the last 100 years (Halmer et al., 2002). The emissions are assumed to be continuously released, because only about $1 / 3$ of explosive emissions are linked to violent explosive phases. The emis- sions are placed between 500 and $1500 \mathrm{~m}$ above each volcano peak.

Continuous degassing is equally distributed over all grid points with GEIA volcano locations. The annual continuous degassing emissions recommend by GEIA are considered to be an underestimate (Graf et al., 1998; Textor et al., 2004). Thus, continuous sulfur-containing emissions of GEIA are multiplied by a factor of 1.5. The new estimate (at $12.6 \mathrm{TgS} / \mathrm{year}$ ) is still conservative, since many volcanoes are either not monitored or have emissions that cannot be accurately detected by satellite sensors presently at use. Continuous degassing emissions are placed in the upper third of the volcano (altitude) to account for degassing at the flanks of the volcanoes. Volcanic $\mathrm{SO}_{2}$ emissions are displayed in Fig. 4.

\subsection{Secondary Organic Aerosol}

Monthly Secondary Organic Aerosol (SOA) emissions are provided. They are based on the assumption that $15 \%$ of natural terpene emissions form SOA, although SOA production is much more complicated (Kanakidou et al., 2005). It is assumed that SOA is formed on time-scales of a few hours and that SOA precursor emissions condense on preexisting aerosol. In reality, substantial SOA formation can occur at higher altitudes (Kanakidou et al., 2005). Terpene emissions of $127 \mathrm{Tg} /$ year were taken from GEIA (Guenther et al., 1995). This translates into an annual global average 
of $19.1 \mathrm{TgPOM} / \mathrm{year}$, which is within bounds of other estimates of 10 to $60 \mathrm{Tg} \mathrm{POM} /$ year (Kanakidou et al., 2005). The spatial distribution of SOA emission, depending on the vegetation type is given in Fig. 5.

\section{Anthropogenically modified emissions - year 2000}

Emissions which have changed (usually sharply increased) with industrialization are: contributions by sulfur - mainly in form of sulfur-dioxide $\left(\mathrm{SO}_{2}\right)$ - and carbon. Carbonaceous emissions are commonly stratified into organic carbon in terms of Particulate Organic Matter (POM) and strongly absorbing black carbon (BC). BC is also often referred to as elemental carbon, although strictly speaking $\mathrm{BC}$ is only the light absorbing fraction of elementary carbon. Primary sources for anthropogenic emissions are large scale (wildland) fires, bio fuel burning including domestic fuel burning and fossil fuel burning. For the latter a distinction is made between sources from road traffic, international shipping, offroad (rail, inland shipping and non-specified transport), industry and power-plants, to account for differences in injection height and particle size, as indicated in Table 2. Table 2 summarizes individual contributions recommended for AeroCom Experiment "B" year 2000 simulations. Details on other emissions are given below.

4.1 Large-scale (wild-land) fire emissions of BC, POM and $\mathrm{SO}_{2}$

Monthly data for large-scale (wild-land) fire emissions of carbon and sulfur are based on the Global Fire Emission Database (GFED) inventory (van der Werf et al., 2004, available online at http://www.ess.uci.edu/ jranders/). In this data-set, satellite derived fire hot spots from TRMM-VIRS and ERS-ATSR are calibrated to burnt area from the MODIS sensor for selected regions, and combined with the CASA biogeochemical model that was previously adjusted to account for fires to estimate fuel loads (van der Werf et al., 2003). The peak in the seasonal cycle of biomass burning emissions derived from fire hot spots has a tendency to precede the peak as derived from atmospheric measurements of $\mathrm{CO}$, especially in the southern hemisphere (Petron et al., 2004). Annual totals are in overall agreement to other estimates (e.g. Generoso et al., 2003; Bond et al., 2004; Hoelzemann et al., 2004), and are further evaluated in Appendix D. Due to strong year-to-year variations, two data-sets are offered: An estimate specifically for to the year 2000 and a 5-year (1997-2001) average for climatological simulations. Year 2000 emissions were below average because of wet $\mathrm{La}$ Niña conditions in the tropics (van der Werf et al., 2004). The annual emission patterns of $\mathrm{BC}, \mathrm{POM}$ and $\mathrm{SO}_{2}$ from large scale biomass burning (wild-land fires) representing the year 2000 are displayed in Fig. 6. Monthly emissions into the
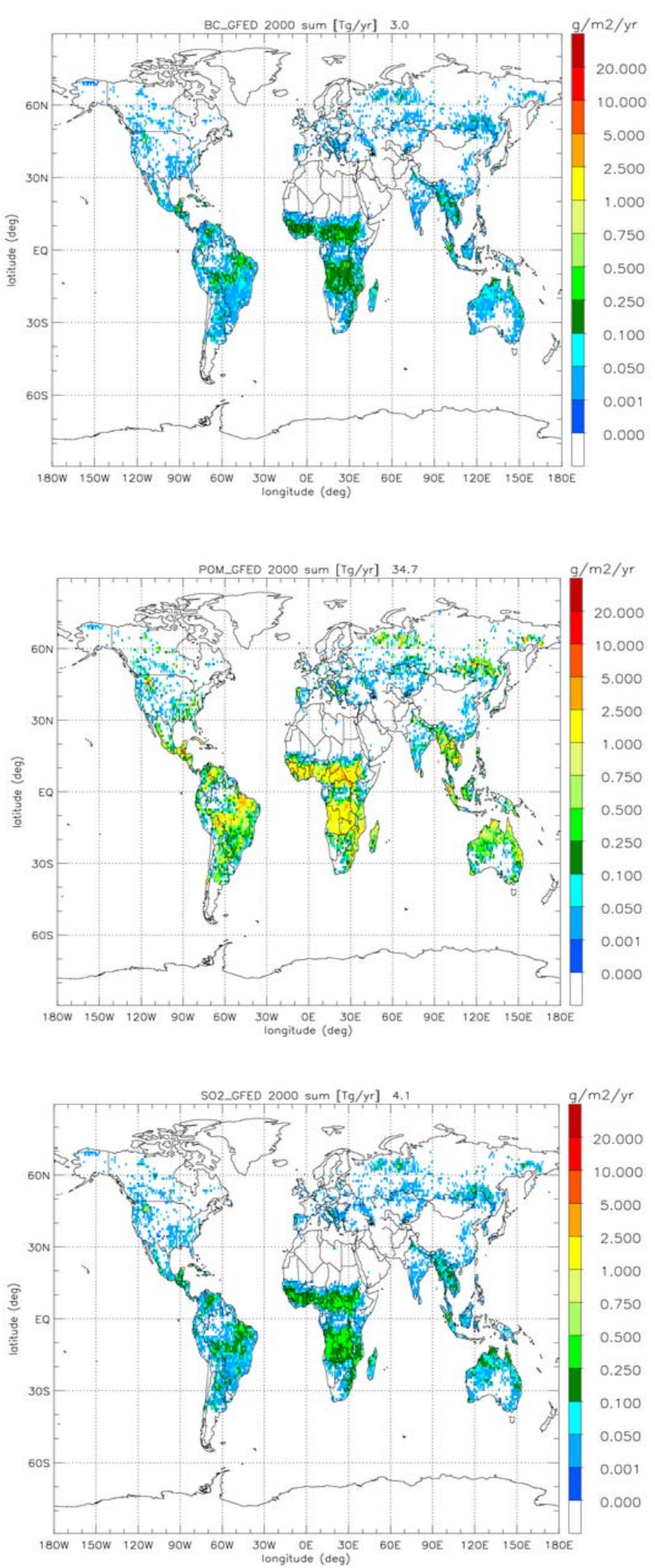

Fig. 6. Annual wild-land fire emissions of BC (upper panel), POM (center panel) and $\mathrm{SO}_{2}$ (lower panel) and for year 2000 . 

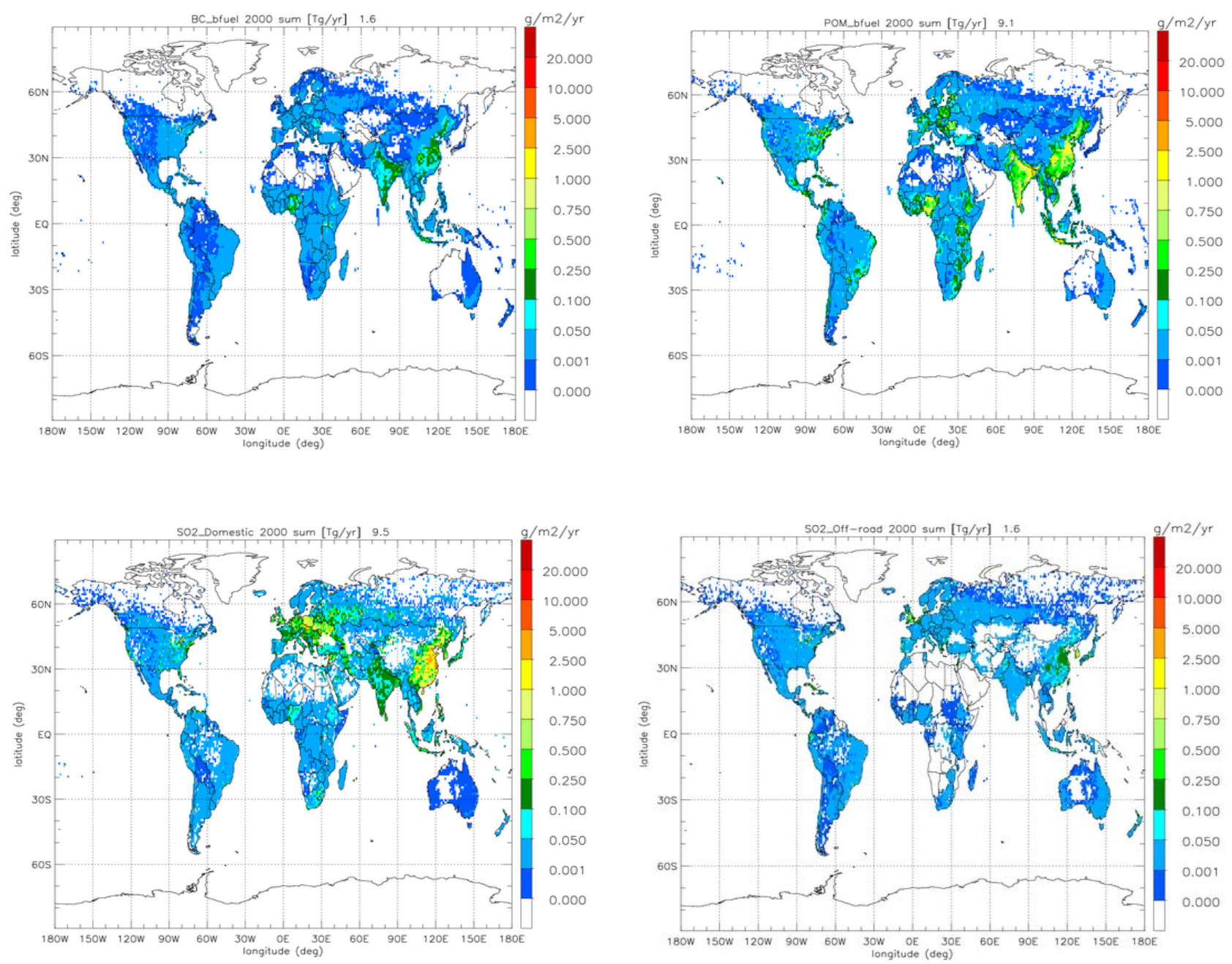

Fig. 7. Annual biofuel emissions of $\mathrm{BC}$ (top left), $\mathrm{POM}$ (top right) and $\mathrm{SO}_{2}$ from domestic (bottom left) and off-road activity (bottom right) for the year 2000 .

atmosphere are distributed over six ecosystem-dependent altitude regimes between the surface and $6 \mathrm{~km}$ (see Sect. 7).

\subsection{Biofuel emissions of $\mathrm{BC}, \mathrm{POM}$, and $\mathrm{SO}_{2}$}

Biofuel emissions include the burning of charcoal and dung and charcoal making. Also included in this category is crop residue burning. Yearly average data (no annual cycle) for biofuel organic emissions are based on the Speciated Particulate Emissions Wizard (SPEW) inventory for 1996 (Bond et al., 2004). When choices for the AeroCom datasets were made, SPEW was (and in 2006 still is) the most detailed attempt to evaluate an emission factor dataset and couple it to energy statistics for 1996. It was assumed that this inventory applies without changes to the year 2000, because it is expected that year 2000 biofuel emissions are well within the uncertainty range of SPEW 1996. Here the uncertain overall impact from changes in energy consumption and in concur- rent technology on biofuel emissions between 1996 and 2000 is a contributing factor. Sulfur-dioxide biofuel emissions for the year 2000 are based on energy statistics for the year 2000 (Cofala et al., 2005). Country and regional estimates (see Appendix B) were gridded following EDGAR (Olivier et al., 2002) distribution patterns (Dentener et al., 2005) and projected from EDGAR estimates for the year 1995. Emission patterns of BC and POM from SPEW and EDGAR based sulfur-dioxide emissions from domestic and off-road sources are displayed in Fig. 7.

\subsection{Fossil-fuel emissions of $\mathrm{BC}, \mathrm{POM}$, and $\mathrm{SO}_{2}$}

Yearly average data (no annual cycle) for fossil-fuel organic emissions are based on the Speciated Particulate Emissions Wizard (SPEW) inventory for 1996 (Bond et al., 2004). It was assumed that this inventory applies without changes to the year 2000. Sulfur-dioxide fossil-fuel emissions are based 

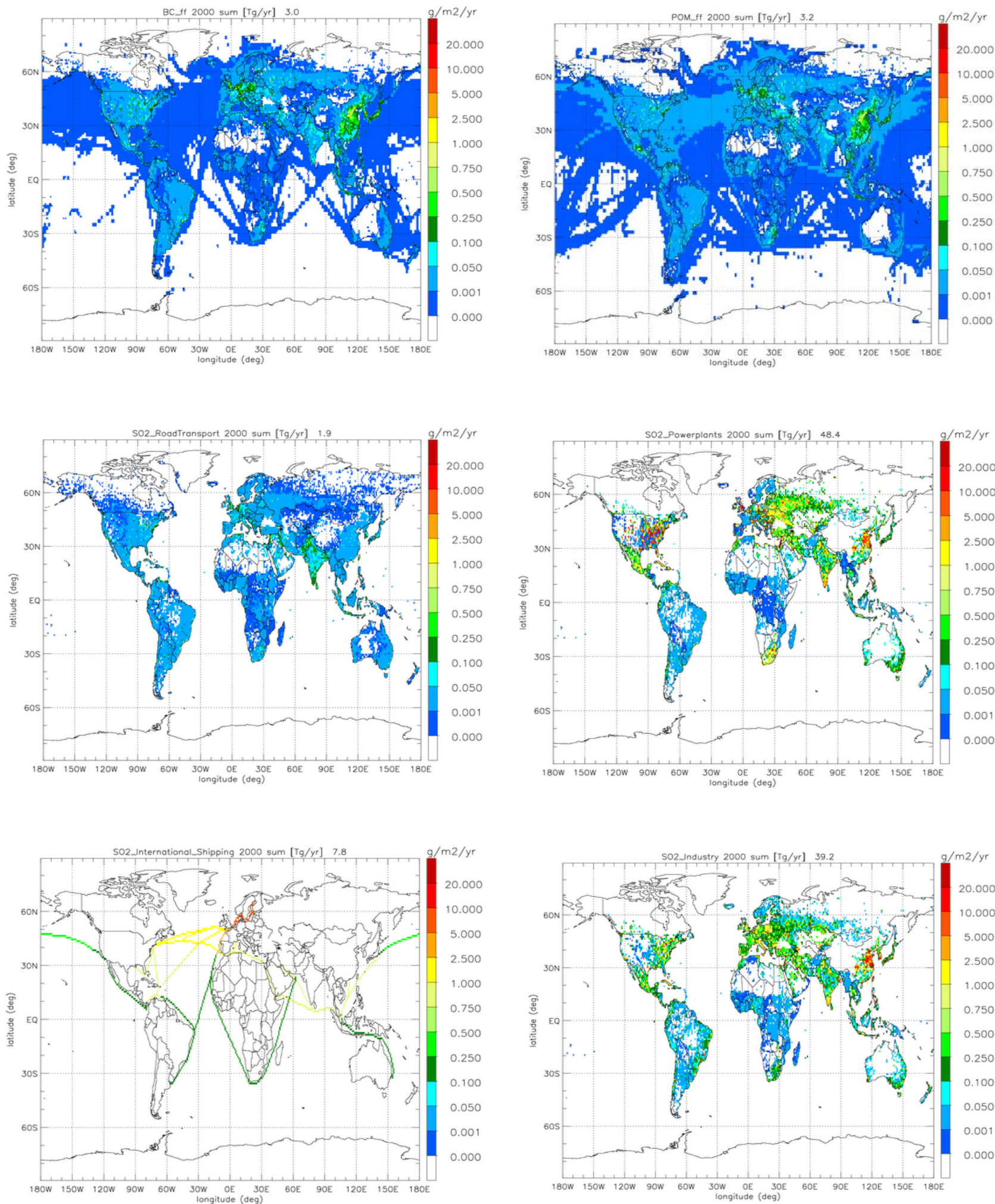

Fig. 8. Annual fossil-fuel emissions of $\mathrm{BC}$ (top left), $\mathrm{POM}$ (top right) and $\mathrm{SO}_{2}$ from road transport (middle left), power-plants (middle right), shipping (bottom left) and industrial activity (bottom right) for the year 2000. For ship emissions over oceans the distribution of the SPEC data-base, as illustrated for $\mathrm{POM}$ or $\mathrm{BC}$ is more realistic than the rather simple distribution in the $\mathrm{EDGAR}$ database, as illustrated for $\mathrm{SO}_{2}$. 
Table 3. AeroCom anthropogenically modified (full molecular mass) emissions for the year 1750 .

\begin{tabular}{|c|c|c|c|c|c|c|c|}
\hline & $\begin{array}{l}\text { time re-solution } \\
\text { solution }\end{array}$ & $\begin{array}{l}\text { aerosol } \\
\text { type* }\end{array}$ & $\begin{array}{l}\text { injection } \\
\text { altitude }\end{array}$ & $\begin{array}{l}\text { size } \ln \\
\mathrm{r}_{m}[\mu \mathrm{m}]\end{array}$ & $\begin{array}{l}\text { size ln } \\
\text { std.dev }\end{array}$ & $\begin{array}{l}\mathrm{r}_{\mathrm{eff}} \\
{[\mu \mathrm{m}]}\end{array}$ & $\begin{array}{l}\text { amount } \\
{[\mathrm{Tg} / \mathrm{yr}]}\end{array}$ \\
\hline \multirow[t]{3}{*}{ wildland fire } & monthly & $\mathrm{BC}$ & 6 layers $H$ & 0.040 & 1.8 & 0.095 & 1.03 \\
\hline & monthly & POM & 6 layers $H$ & 0.040 & 1.8 & 0.095 & 12.8 \\
\hline & monthly & $\mathrm{S}^{+}$ & 6 layers $H$ & 0.040 & 1.8 & 0.095 & 1.46 \\
\hline \multirow[t]{2}{*}{ biofuel } & yearly & $\mathrm{BC}$ & surface & 0.040 & 1.8 & 0.095 & 0.39 \\
\hline & yearly & POM & surface & 0.040 & 1.8 & 0.095 & 1.56 \\
\hline domestic & yearly & $\mathrm{S}^{+}$ & surface & 0.040 & 1.8 & 0.095 & 0.12 \\
\hline
\end{tabular}

* S-sulfur $\left[\mathrm{m}(\mathrm{S})=0.5^{*} \mathrm{~m}\left(\mathrm{SO}_{2}\right.\right.$, $)$ or $\left.\mathrm{m}(\mathrm{S})=0.33 * \mathrm{~m}\left(\mathrm{SO}_{4}\right)\right]$, POM-particulate organic matter [=1.40*organic carbon], BC-black carbon

$+2.5 \%$ of sulfur should be emitted as particulate $\mathrm{SO}_{4}$, most sulfur $(\mathrm{S})$ is emitted as gaseous $\mathrm{SO}_{2}$

${ }^{H}$ 0-100 m, 100-500 m, 500-1000 m, 1-2 km, 2-3 km, 3-6 km, assignment according to Table 4

on energy statistics for the year 2000 using technology controlled emission factors from IIASA/RAINS (Cofala et al., 2005). The country and region estimates (see Appendix B) were gridded following EDGAR (Olivier et al., 2002) distribution patterns (Dentener, 2005). Ship traffic for the year 2000 is assumed to have increased by $1.5 \%$ per year since 1995 over the EDGAR3.2 values. Fossil fuel emission pattern for $\mathrm{BC}$ and $\mathrm{POM}$ and $\mathrm{SO}_{2}$ emission patterns from road traffic, power-plants, ship-traffic and industry for the year 2000 are displayed in Fig. 8.

\subsection{More emissions}

For additional emission data (e.g. for full chemistry simulations) it is recommended to use the EDGAR 3.2, 1995 database (Olivier et al., 2002; http://www.mnp.nl/edgar). No specific recommendations are given for oxidant fields.

\section{Anthropogenically modified emissions - year 1750}

With the exception of fossil fuel emissions, which can be neglected, anthropogenic emissions in pre-industrial times were small but not zero. In particular contributions from wild-land fires (open burning) and biofuel emissions in inhabited regions must be considered. In the absence of observational data, emission estimates for AeroCom Experiment "Pre" (year 1750) are derived from educated-guess assumptions. Recommendations for AeroCom Experiment "Pre" (year 1750) simulations are summarized in Table 3.

\subsection{Large-scale (wild-land) fire emissions of BC, POM and $\mathrm{SO}_{2}$}

Pre-industrial wild-land fire emissions are based on scaled five-year averages (1998-2002) of monthly data of the Global Fire Emission Database (GFED) inventory (van der Werf et al., 2003, 2004; Randerson et al., 2005). Central to a rescaling is the (year 1750 to year 1990) population ratio from the "Hundred Year database for Integrated Environmental Assessments" (HYDE) data-set (Klein-Goldewijk and Battjes, 1997; http://www.rivm.nl/hyde, see also Table B3 in Appendix B).

Actual scaling corrections are then performed according to present day land cover (Olsen et al., 1985). Emissions from deforestation fires are scaled by population whereas emissions over all other land-surfaces (e.g. grassland, shrub/bush, agricultural activity) scale only to $60 \%$ by population (as it is assumed that $40 \%$ burns anyhow). Forest emissions in high latitudes of the northern hemisphere (Europe, N. America, Russia) are doubled from current estimates, to account for less fire suppression in the past (Brenkert et al., 1997).

\subsection{Biofuel emissions of $\mathrm{BC}, \mathrm{POM}$, and $\mathrm{SO}_{2}$}

Pre-industrial biofuel estimates are derived separately for carbonaceous aerosol and sulfur emissions. The BC and POM contributions are scaled back to the year 1750 based on statistics for population and crop production (where differences between developing and developed countries are considered). Pre-industrial carbon emissions are tied to the wood consumption, where the switch from electricity or natural gas as predominant cooking fuel back in time to wood was considered (Ito and Penner, 2005). For sulfur-dioxide a CO biofuel inventory for the year 1890 (van Aardenne et al., 2001) is multiplied by 0.00346 , based on the ratio of emission factor estimates (Andreae and Merlet, 2001) for $\mathrm{SO}_{2}$ and $\mathrm{CO}$ ( $0.27 \mathrm{~g}$ and $78 \mathrm{~g}$ per $\mathrm{kg}$ of burned dry biomass, respectively). A "year 1750-to-year 1890" population ratio from the HYDE data-set (see Appendix B) establishes the emissions for the year 1750. Emissions at high latitudes in the northern hemisphere (Europe, N. America and Russia) are doubled to account for a higher per person use (Brenkert et al., 1997). 


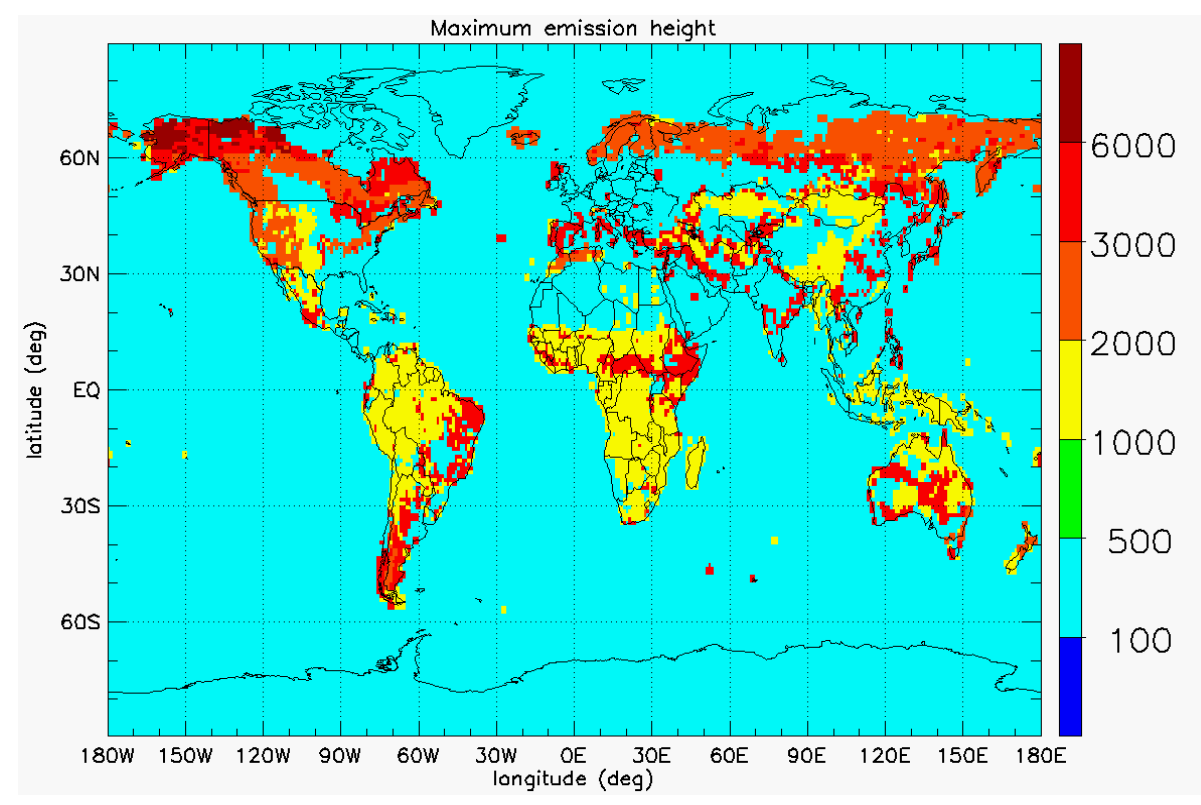

Fig. 9. Maximum emission height (in meter) for (large-scale) wild-fire aerosol.

Table 4. Fractional distribution (in \%) of emission heights for wild-land fires.

\begin{tabular}{lllllll}
\hline & $0-$ & $100-$ & $500-$ & $1000-$ & $2000-$ & $3000-$ \\
& $100 \mathrm{~m} *$ & $500 \mathrm{~m}$ & $1000 \mathrm{~m}$ & $2000 \mathrm{~m}$ & $3000 \mathrm{~m}$ & $6000 \mathrm{~m}$ \\
\hline agricultural waste & 100 & - & - & - & - & - \\
tropical (30 S-30 N) & 20 & 40 & 40 & - & - & - \\
Temperate (30 N-60 N, 30 S-60 S) & 20 & 20 & 20 & 40 & - & - \\
Boreal (Eurasia) & 10 & 10 & 20 & 20 & 40 & - \\
Boreal (Canada) & 10 & 10 & 10 & 10 & 20 & 40 \\
\hline
\end{tabular}

* contributions assigned to heights below the actual surface altitude are moved into the lowest applicable height range and contribution of the $0-100 \mathrm{~m}$ altitude are always emitted in the lowest modeling layer.

\section{Temporal resolution}

The temporal resolution of the individual datasets is given in Tables 1 to 3. For simplification all anthropogenic enhanced emissions have no inter-annual variation - except for large scale wild-land fires, where a monthly resolution is necessary to represent their (dry-) seasonal character. For all natural emissions that are tied to near surface winds (e.g. DU, SS, DMS) a daily temporal resolution was selected as a compromise between detail and size of the data-sets. The original simulations on which daily emissions are based on were done at a much higher temporal resolution.

\section{Injection height}

Recommended injection heights above the earth surface of the individual emission datasets are given in Tables 1 to 3 .
Most emissions are assumed to be evenly distributed in the lowest model-layer ("surface"). Fossil fuel emissions from industry and power-plants should be injected between 100 and $300 \mathrm{~m}$ above the surface, because these emissions are usually released at the top of chimneys. Large-scale wildland fire emissions are released distributed over six altitude regimes: $0-100 \mathrm{~m}, 100-500 \mathrm{~m}, 500-1 \mathrm{~km}, 1-2 \mathrm{~km}, 2-3 \mathrm{~km}$, $3-6 \mathrm{~km}$ according to wild-land fire location and type based on detailed work by D. Lavoue (2003, personal communication). Table 4 lists the altitude distribution by type.

Emissions are distributed evenly within each altitude layer. Contributions assigned to heights below the actual surface altitude are moved into the lowest applicable height range while contributions assigned to the $0-100 \mathrm{~m}$ altitude are always emitted in the lowest model layer. For illustration purposes also the maximum emission height for wild-land fire emissions is indicated in Fig. 9. 
The most complex altitude assignment is for volcanic emission. It is based on a data-set for volcanic location and volcano top altitude $\left[\mathrm{V}_{\mathrm{T}}\right]$ (Halmer et al., 2002). For each volcano, (continuous) explosive contributions should be evenly placed between 500 and $1500 \mathrm{~m}$ above $\mathrm{V}_{\mathrm{T}}$ and continuous degassing should occur in the upper $1 / 3$ altitude of each volcano.

\section{Size choices for primary particulate emissions}

Recommended aerosol sizes for particles of the individual emission datasets are given in Tables 1 to 3 . Size recommendations are given in terms of log-normal distributions parameters, where the mode radius $\left(\mathrm{r}_{\mathrm{m}}\right)$ describes the peak concentration and the standard deviation $(\sigma)$ describes the distribution width. From both log-normal values a (radiatively) characteristic size has been determined $\left(r_{\text {eff }}\right)$, as the ratio between the sums of the third and the second moment of the radius: $\Sigma \mathrm{r}^{3} / \Sigma \mathrm{r}^{2}$.

For wildland fire (open burning) and biofuel aerosol the recommended characteristic size of $\mathrm{r}_{\mathrm{eff}} \sim 0.1 \mu \mathrm{m}$ is based on an analysis of numerous field-measurements (see Appendix C). For fossil-fuel two different size-distributions are defined. A large size mode with $\mathrm{r}_{\text {eff }} \sim 1.7 \mu \mathrm{m}$ is recommended for power-plant and industrial emissions (representing fly-ash, and components formed on it). A relatively small size mode with $\mathrm{r}_{\text {eff }} \sim 0.04 \mu \mathrm{m}$ is recommended for other fossil fuel emissions (e.g. traffic) based on kerbside measurements in several EU-cities (Putaud et al., 2004; van Dingenen et al., 2004). For particles from volcanic emissions, half of the mass is assigned each to the small fossil-fuel size $\left(\mathrm{r}_{\text {eff }} \sim 0.04 \mu \mathrm{m}\right)$ and to the biofuel size $\left(\mathrm{r}_{\text {eff }} \sim 0.1 \mu \mathrm{m}\right)$. For dust and sea-salt, size recommendations are more complex, because they are defined by two and three size-modes, respectively, with variations permitted between consecutive days. However, since the mass flux is dominated by contributions of the coarse size domain, the average characteristic size is well represented by the coarse mode with $\mathrm{r}_{\text {eff }} \sim 2.1 \mu \mathrm{m}$ for dust and at $\mathrm{r}_{\mathrm{eff}} \sim 2.5 \mu \mathrm{m}$ for sea-salt.

\section{Discussion and conclusion}

The above emissions, recommended for AeroCom, represent the state-of-the-art for global aerosol emissions inventories in the year 2004. In cases where several alternative datasets were available, such as three large-scale burning wild-land fire inventories (van der Werf et al., 2004; Generoso et al., 2003; Hoelzemann et al., 2004; see Appendix D), selection criteria included global annual coverage, lack of biases and emission-fluxes within expected bounds. The overall goal was to provide global emission fields and recommendations for seasonality, emission height, and size distribution of all aerosol sources that are simple enough to be easily implemented in global models.
The data-sets explained in this paper are considered an initial first step to establish a global and temporal sufficiently comprehensive aerosol emission database. This work did not attempt to assess uncertainties; nevertheless it should be recognized that there is more confidence in some sources (like $\mathrm{SO}_{2}$ from anthropogenic sources) than in other sources (e.g. emissions of EC and POM) where there are deviations of a factor of 3 between estimates found in the literature. Inadequate temporal resolution is another source for uncertainties. In particular the lack of an annual cycle for most anthropogenically modified emissions is a large simplification (De Meijr et al., 2006). Similarly, the daily resolution for dust and sea-salt seem inadequate, since their simulated emissions are tied to the strength of near-surface winds and their variability. In that context, potential uncertainties introduced by the inconsistency with respect to the applied year 2000 wind fields for dust and sea-salt appear minor. In fact, a study comparing dust mobilization due to the use of different (NCEP, NASA GEOS-DAS) surface winds for the same year leads to fairly consistent fields - except for some differences over East Asia and Australia (Luo et al., 2003).Also note that dust applies wind data only over land, whereas sea-salt applies wind data only over oceans.

In summary, improvements should address (1) higher temporal resolutions for all aerosol emissions (by providing at least seasonality to all emissions), (2) consistency for needed ancillary data (e.g. identical meteorological fields and years, when simulating emission for sea-salt, dust and DMS) and (3) consistencies to simultaneously released tracegas emissions (e.g. during wild-land fires) that are relevant to atmospheric chemistry. In addition, an extension to include emission-estimates associated with future scenarios is planned.

\section{Appendix A}

\section{Names and location of data-files on IES, JRC ftp-web site}

All AeroCom emission data-sets are available (in netcdf data format) via a dedicated file transfer site at the Joint Research Center in Ispra, Italy: ftp://ftp.ei.jrc.it/pub/Aerocom/. To help locate specific data ftp-site subdirectories and their content is outlined below:

/dust_ncf dust data "dust200001.nc" (Jan 2000), ..., "dust200012.nc" (Dec 2000)

/seasalt_ncf salt data "salt200001.nc" (Jan 2000), ..., "salt200012.nc" (Dec 2000)

/DMS_ncf DMS data "dms200001.nc" (Jan 2000), ..., "dms200012.nc" (Dec 2000) 
/volcanic_ncf volcanic data

- degassing "contineous_volc.nc"

- explosive "explosive_volc.nc"

/other_ncf 2000 all other emissions for the year 2000

- BC-biofuel "BC1bfuel.nc"

- BC-fossil fuel "BC1ff.nc"

- BC-wildland fire "GFED_2000_BC.nc"

“GFED_average_1997-2002_BC.nc”

- POM-wildland fire "GFED_2000_POM.nc”

“GFED_average_1997-2002_POM.nc”

- SO2-wildland fire "GFED_2000_SO2_nc"

“GFED_average_1997-2002_SO2.nc”

- POM-biofuel "POMbfuel.nc"

- POM-fossil fuel "POMff.nc"

- SO2-domestic "SO2_Domestic_2000bau.nc"

- SO2-industry "SO2_Industry_2000bau.nc"

- SO2-ships "SO2_International_Shipping_2000bau.nc"

- SO2-off road "SO2_Off-road_2000bau.nc"

- SO2-powerplant "SO2_Powerplants_2000bau.nc"

- SO2-traffic "SO2_RoadTransport_2000bau.nc"

- POM-SOA "SOA.nc"

/other_ncf_1750 all other emissions for the year 1750

- BC-biofuel "BC1_1750_bfuel.nc"

- BC-wildland fire "GFED_1750_BC.nc"

- POM-wildland fire "GFED_1750_POM.nc"

- SO2-wildland fire "GFED_1750_SO2_nc"

- POM-biofuel "POM_1750_bfuel.nc"

- SO2-domestic "SO2_Domestic_1750bau.nc"

- POM-SOA "SOA.nc”

\section{Appendix B}

\section{Regional aspects of AeroCom emissions}

For a quick reference on regional contributions of $\mathrm{BC}, \mathrm{POM}$ and $\mathrm{SO}_{2}$, annual AeroCom emissions are stratified into 18 regions according to the IMAGE integrated assessment model, as illustrated in Fig. B1 (courtesy of B. Eickhout at RIVM, Netherlands).

Regional AeroCom emissions by species and source are summarized for current conditions (year 2000) in Table B1. Figures B2, B3 and B4 display the global distribution of annual emission totals for $\mathrm{BC}, \mathrm{POM}$ and $\mathrm{SO}_{2}$ for the year 2000, combining all sources.

Corresponding to Table B1 regional distributions for preindustrial conditions (year 1750) are given in Table B2. Figures B5, B6 and B7 display the global distribution of annual emission totals for $\mathrm{BC}, \mathrm{POM}$ and $\mathrm{SO}_{2}$ for the year 1750, combining all sources. Differences of emissions between years 2000 and 1750 provide estimates on anthropogenic contributions.

A central role, when back-scaling current emission to obtain estimates on pre-industrial emissions has been the population ratio of the HYDE data-set (http://www.rivm.nl/hyde). In particular the $1990 / 1750$ and the $1890 / 1750$ population ratios were applied and are listed among others for the 18 IMAGE regions (see Fig. B1) in Table B3.

\section{Appendix C}

\section{Background to the sizing of primary aerosol from biomass burning}

Biomass burning is one of the main sources for carbonaceus aerosol in the atmosphere. Globally it contributes to about $40 \%$ of $\mathrm{CO}_{2}, 32 \%$ of $\mathrm{CO}, 38 \%$ of tropospheric ozone, $7 \%$ of total particulate matter and $39 \%$ of particulate organic carbon. The majority of biomass aerosol (ca 80\%) occurs in the tropics as seasonal event (e.g. Aug-Oct: S. Africa and S. America).

To provide background on choices for the sizing of freshly emitted (young) biomass aerosol. We compiled a summary of measurements (Allen and Miguel, 1995; Anderson et al., 1996; Andreae and Merlet, 2001; Cachier et al. 1996; LeCanut et al., 1996; Radke et al., 1991; Scholes et al., 1996; Suscott et al., 1991). Measured size distributions have been fitted to a multi-model lognormal distribution, which is defined by

$\frac{d N}{d \ln r}=\frac{N \ln 10}{\sqrt{2 \pi} \ln \sigma} \cdot \exp \left[-\frac{\left(\ln r-\ln r_{m}\right)^{2}}{2(\ln \sigma)^{2}}\right]$

where $N$ is total particle number, $\mathrm{r}_{\mathrm{m}}$ is the mode radius and $\sigma$ is the standard deviation. A comparison of fits is presented in Fig. C1. 


\section{RIVM Environmental Research -1998 World Regions and Subregions}

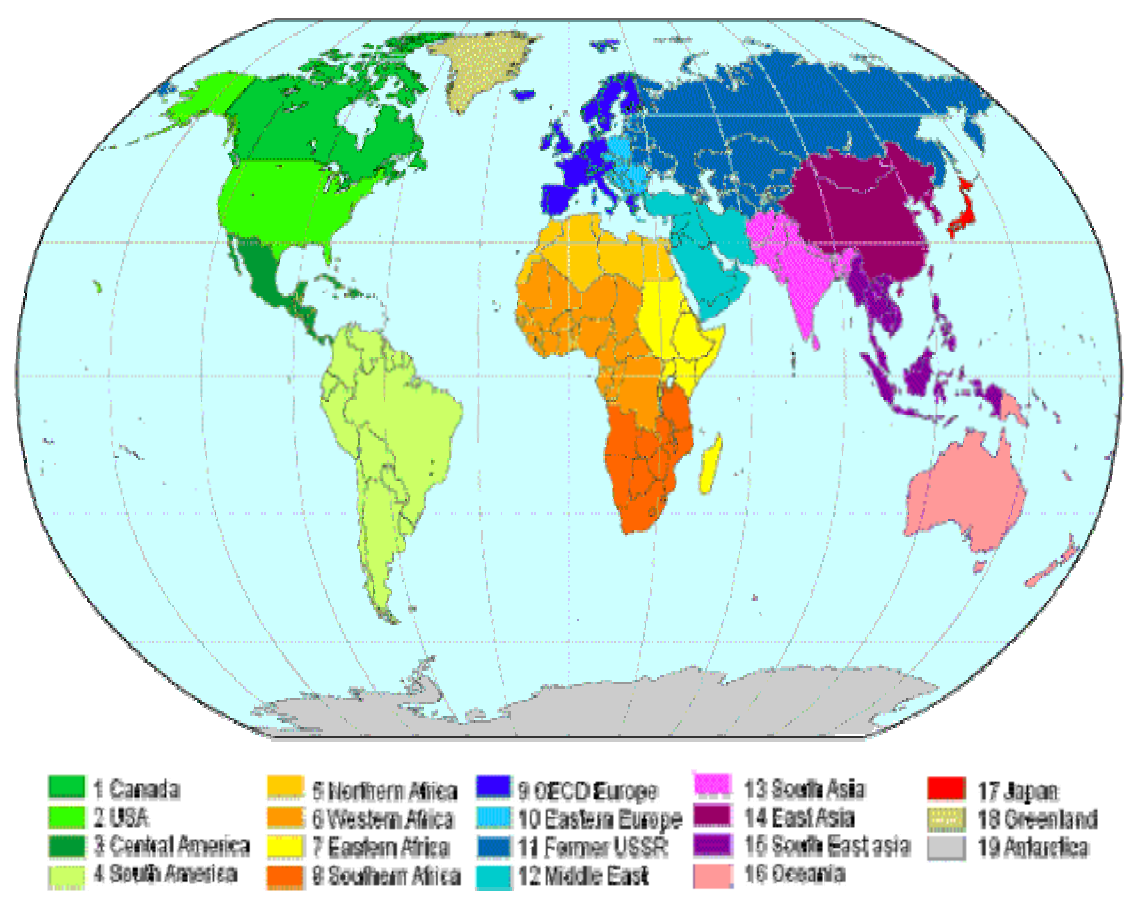

Fig. B1. Regional choices for continental regions by the IMAGE project (by B. Eickhout).

Table B1. Regional distributions of AeroCom emissions for the year 2000 (in Tg/year).

\begin{tabular}{|c|c|c|c|c|c|c|c|c|c|c|c|c|c|c|c|c|c|c|c|}
\hline category & $\begin{array}{l}\mathrm{BC} \\
\text { wildf }\end{array}$ & $\begin{array}{l}\mathrm{BC} \\
\text { biof }\end{array}$ & $\begin{array}{l}\mathrm{BC} \\
\text { fos.f }\end{array}$ & $\begin{array}{l}\text { BC } \\
\text { all }\end{array}$ & $\begin{array}{l}\text { POM } \\
\text { wildf }\end{array}$ & $\begin{array}{l}\text { POM } \\
\text { biof }\end{array}$ & $\begin{array}{l}\text { POM } \\
\text { fosf }\end{array}$ & $\begin{array}{l}\text { POM } \\
\text { soa }\end{array}$ & $\begin{array}{l}\text { POM } \\
\text { all }\end{array}$ & $\begin{array}{l}\mathrm{SO}_{2} \\
\text { wildf }\end{array}$ & $\begin{array}{l}\mathrm{SO}_{2} \\
\text { v.ex }\end{array}$ & $\begin{array}{l}\mathrm{SO}_{2} \\
\text { v.co }\end{array}$ & $\begin{array}{l}\mathrm{SO}_{2} \\
\text { dom }\end{array}$ & $\begin{array}{l}\mathrm{SO}_{2} \\
\text { road }\end{array}$ & $\begin{array}{l}\mathrm{SO}_{2} \\
\text { pow }\end{array}$ & $\begin{array}{l}\mathrm{SO}_{2} \\
\text { off-r }\end{array}$ & $\begin{array}{l}\mathrm{SO}_{2} \\
\text { ship }\end{array}$ & $\begin{array}{l}\mathrm{SO}_{2} \\
\text { indu }\end{array}$ & $\begin{array}{l}\mathrm{SO}_{2} \\
\text { all }\end{array}$ \\
\hline CANADA & 0.01 & 0.01 & 0.03 & 0.05 & 0.18 & 0.05 & 0.02 & 0.69 & 0.95 & 0.02 & 0 & 0 & 0.07 & 0.01 & 0.54 & 0.05 & 0 & 1.19 & 1.88 \\
\hline USA & 0.07 & 0.06 & 0.27 & 0.40 & 1.11 & 0.45 & 0.2 & 1.23 & 2.99 & 0.11 & 0.22 & 1.01 & 0.31 & 0.17 & 12.4 & 0.11 & 0 & 3.12 & 17.5 \\
\hline C AMERICA & 0.13 & 0.03 & 0.06 & 0.22 & 1.5 & 0.18 & 0.14 & 0.62 & 2.45 & 0.14 & 0.23 & 2.24 & 0.04 & 0.08 & 1.84 & 0.08 & 0 & 1.36 & 6 \\
\hline S AMERICA & 0.73 & 0.08 & 0.22 & 1.03 & 8.3 & 0.5 & 0.24 & 6.58 & 15.6 & 0.85 & 0.47 & 4.76 & 0.16 & 0.22 & 0.54 & 0.12 & 0.01 & 1.61 & 8.72 \\
\hline N AFRICA & 0 & 0 & 0.05 & 0.05 & 0 & 0.03 & 0.06 & 0.03 & 0.12 & 0 & 0 & 0 & 0.05 & 0.07 & 0.68 & 0.01 & 0 & 0.64 & 1.45 \\
\hline W AFRICA & 0.73 & 0.18 & 0.01 & 0.92 & 7.65 & 0.97 & 0.04 & 2.53 & 11.2 & 1.01 & 0.02 & 0 & 0.14 & 0.04 & 0.06 & 0.03 & 0 & 0.14 & 1.43 \\
\hline E AFRICA & 0.25 & 0.08 & 0.01 & 0.34 & 2.65 & 0.44 & 0.01 & 0.7 & 3.80 & 0.35 & 0.17 & 0.02 & 0.09 & 0.01 & 0.03 & 0.01 & 0 & 0.08 & 0.77 \\
\hline S AFRICA & 0.56 & 0.07 & 0.05 & 0.69 & 5.81 & 0.4 & 0.09 & 0.94 & 7.24 & 0.83 & 0.03 & 0.02 & 0.12 & 0.05 & 1.79 & 0.02 & 0 & 0.64 & 3.5 \\
\hline OECD EU & 0.01 & 0.03 & 0.25 & 0.28 & 0.11 & 0.21 & 0.17 & 0.33 & 0.81 & 0.01 & 0.08 & 0 & 0.44 & 0.14 & 3.47 & 0.19 & 0.08 & 2.05 & 6.47 \\
\hline EAST EU & 0.01 & 0.03 & 0.1 & 0.14 & 0.12 & 0.28 & 0.1 & 0.08 & 0.58 & 0.01 & 0 & 0 & 0.67 & 0.03 & 4.2 & 0.04 & 0 & 1.01 & 5.96 \\
\hline F. USSR & 0.08 & 0.02 & 0.17 & 0.27 & 1.81 & 0.14 & 0.17 & 0.98 & 3.10 & 0.15 & 0.14 & 0 & 1.16 & 0.06 & 5.61 & 0.12 & 0 & 3.99 & 11.2 \\
\hline MID EAST & 0 & 0.01 & 0.12 & 0.13 & 0 & 0.06 & 0.24 & 0.12 & 0.42 & 0 & 0.03 & 0 & 0.49 & 0.25 & 2.8 & 0.06 & 0.07 & 2.44 & 6.14 \\
\hline SOUTH ASIA & 0.04 & 0.40 & 0.18 & 0.61 & 0.38 & 2.14 & 0.14 & 0.69 & 3.35 & 0.05 & 0 & 0 & 0.59 & 0.44 & 3.49 & 0.13 & 0 & 2.89 & 7.6 \\
\hline EAST ASIA & 0.01 & 0.41 & 1.01 & 1.42 & 0.21 & 2.03 & 0.93 & 0.69 & 3.87 & 0.02 & 0.02 & 0 & 4.75 & 0.12 & 8.76 & 0.44 & 0 & 15.2 & 29.3 \\
\hline SE ASIA & 0.20 & 0.15 & 0.14 & 0.50 & 2.24 & 0.8 & 0.19 & 1.49 & 4.72 & 0.21 & 0.44 & 0.79 & 0.38 & 0.15 & 1.05 & 0.06 & 0.02 & 1.6 & 4.7 \\
\hline OCEANIA & 0.23 & 0 & 0.03 & 0.26 & 2.56 & 0.02 & 0.02 & 0.97 & 3.57 & 0.33 & 0.11 & 4.52 & 0.01 & 0.04 & 0.85 & 0.04 & 0 & 0.81 & 6.71 \\
\hline JAPAN & 0 & 0 & 0.14 & 0.15 & 0.01 & 0 & 0.09 & 0.05 & 0.15 & 0 & 0.22 & 2.57 & 0.07 & 0.04 & 0.25 & 0.04 & 0 & 0.48 & 3.66 \\
\hline GREENLAND & 0 & 0 & 0 & 0 & 0 & 0 & 0 & 0 & 0 & 0 & 0 & 0 & 0 & 0 & 0 & 0 & 0 & 0 & 0 \\
\hline OCEAN & 0 & 0.07 & 0.21 & 0.27 & 0 & 0.39 & 0.35 & 0.4 & 1.14 & 0 & 1.83 & 9.29 & 0 & 0 & 0 & 0 & 7.58 & 0 & 18.7 \\
\hline WORLD & 3.04 & 1.63 & 3.04 & 7.72 & 34.7 & 9.09 & 3.2 & 19.1 & 66.1 & 4.1 & 4 & 25.2 & 9.55 & 1.92 & 48.4 & 1.56 & 7.75 & 39.2 & 142. \\
\hline
\end{tabular}

wildf - wildfire, biof - biofuel, fos.f - fossil fuel, v.ex - volcanic, explosive, v.co - volcanic, continuous, dom - domestic, road - road traffic, pow - powerplant , off-r - off road, ship - shipping, indu - industry

The accumulation size-mode (radii smaller than $0.5 \mu \mathrm{m}$ ) usually contains more than $90 \%$ of the biomass burning aerosol mass. Figure $\mathrm{C} 2$ presents the log-normal parameters data-pairs for $\mathrm{r}_{\mathrm{m}}$ (actually the diameter is shown) and $\sigma$ of only the accumulation size-mode associated with the size distributions of Fig. C1.
Data points in the lower right of Fig. C2 indicate lognormal parameters from fits to young biomass aerosol. As the biomass aerosol ages, the mode radius increases and the distribution width narrows, resulting in an increase to effective radius (from 0.10 to $0.15 \mu \mathrm{m}$ ), which is small in the context of orders of magnitudes among different aerosol sizes. 


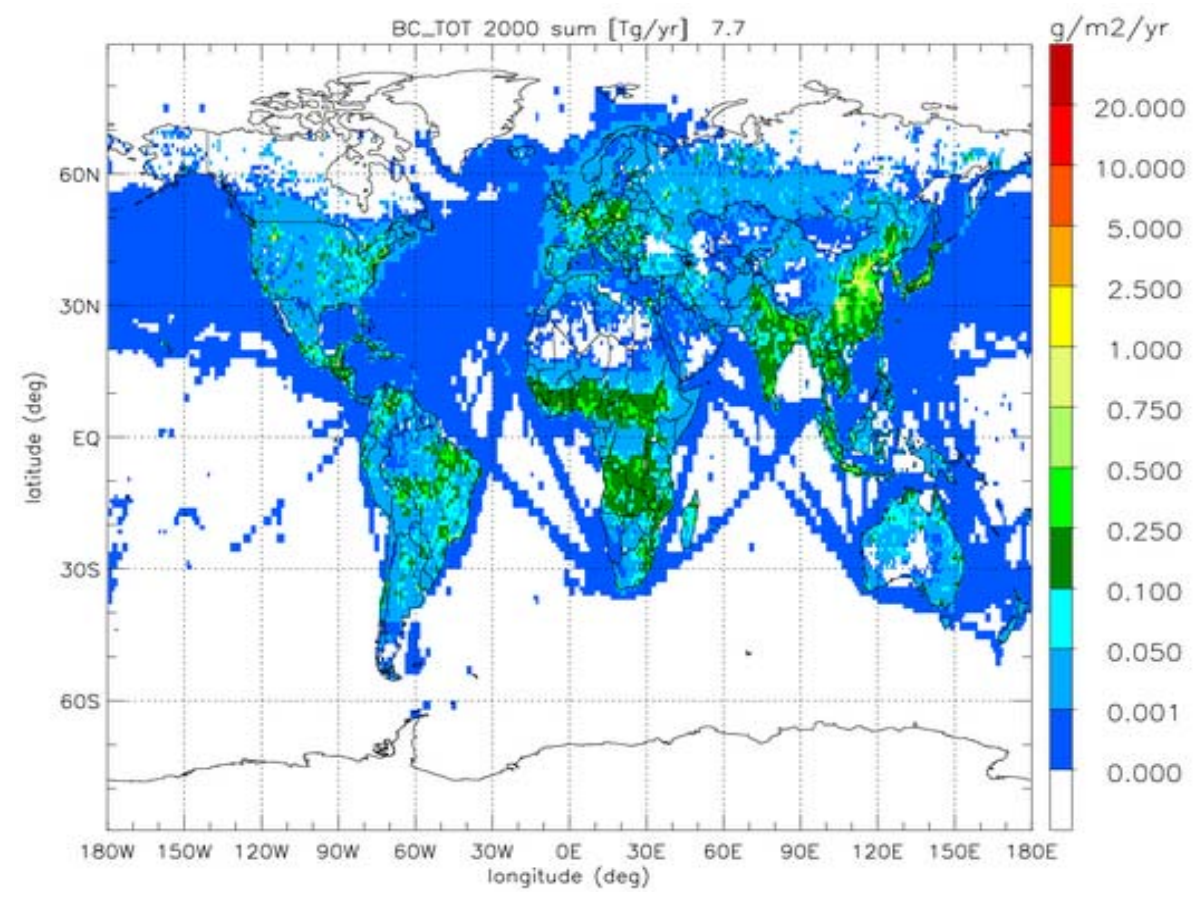

Fig. B2. Global distribution of all BC emissions for the year 2000.

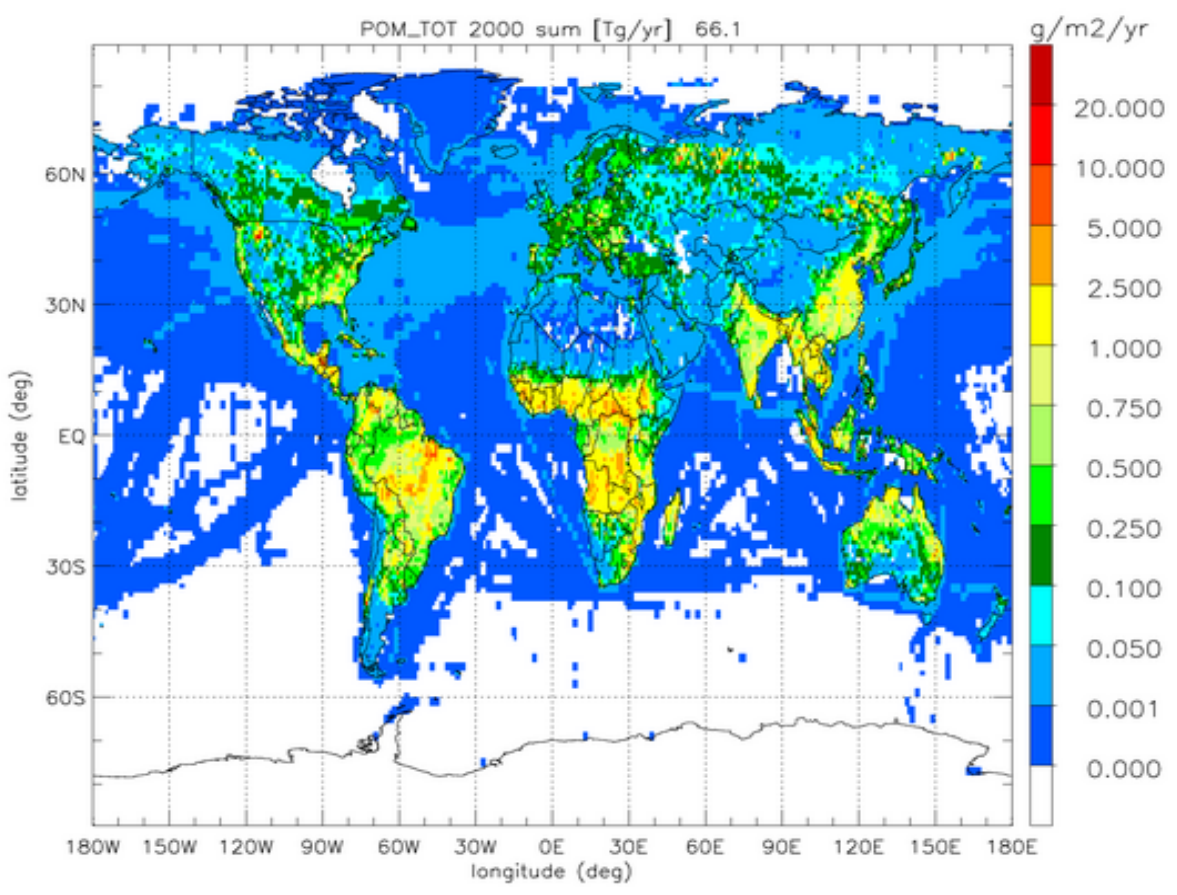

Fig. B3. Global distribution of all POM emissions for the year 2000.

As biomass burning emissions are associated with young aerosol, recommendations are $0.04 \mu \mathrm{m}$ for (number-) mode radius $\mathrm{r}_{\mathrm{m}}$ and 1.8 for standard deviation $\sigma$ gas listed in Tables 1 to 3 ). These values are consistent with estimates of volatility analysis on young aerosol emitted by North American fires (Reid et al., 2003), where sampled aerosol $\left(\mathrm{r}_{\mathrm{m}}=0.55 \mu \mathrm{m}, \sigma=1.7\right)$ has been pre-heated to $310^{\circ} \mathrm{C}$, to bake off volatile compounds (organics, sulfate, nitrate, water etc.), 


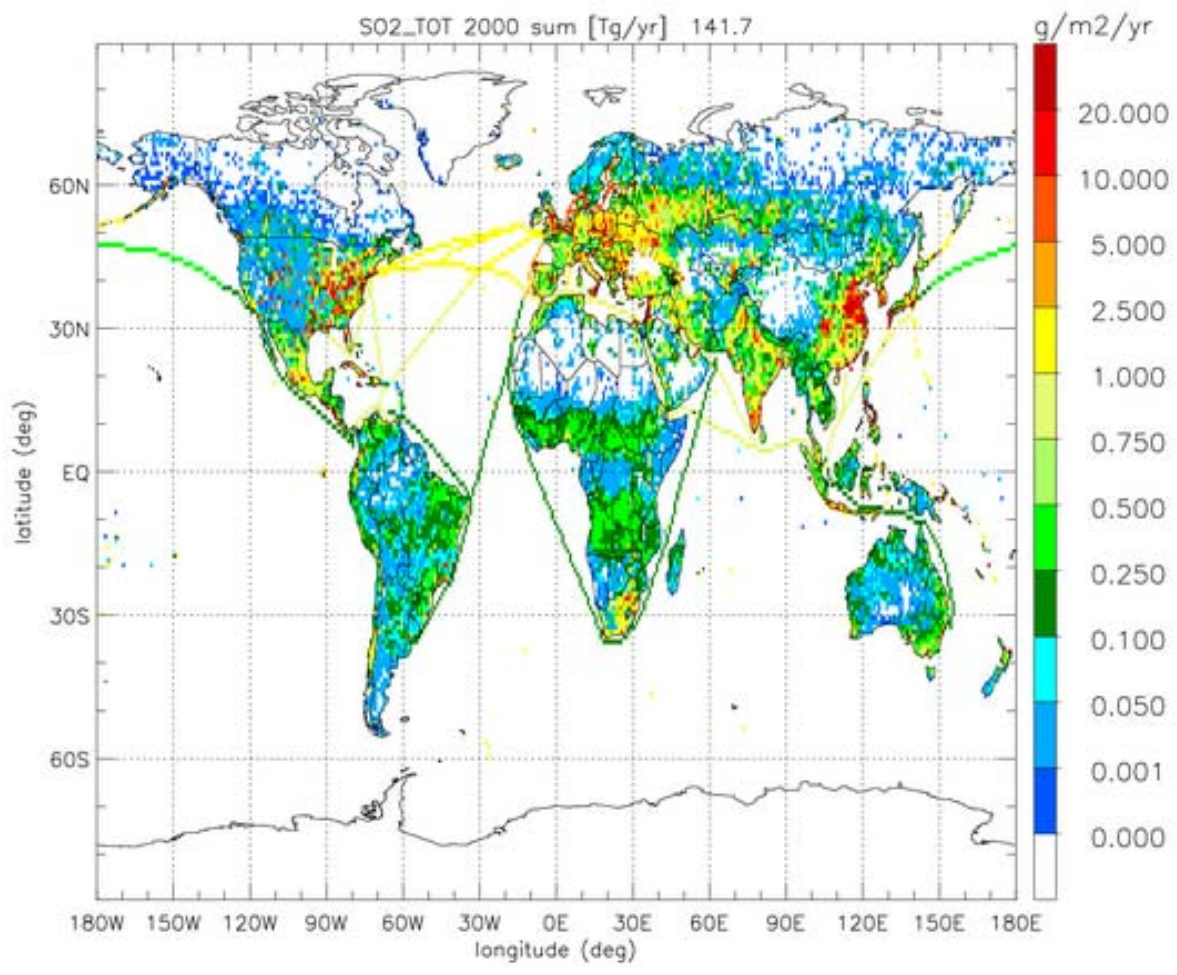

Fig. B4. Global distribution of all $\mathrm{SO}_{2}$ emissions for the year 2000.

Table B2. Regional distributions of AeroCom emissions for the year 1750 (in $\mathrm{Tg} / \mathrm{year}$ ).

\begin{tabular}{|c|c|c|c|c|c|c|c|c|c|c|c|c|c|c|c|c|c|c|c|}
\hline category & $\begin{array}{l}\mathrm{BC} \\
\text { wildf }\end{array}$ & $\begin{array}{l}\text { BC } \\
\text { biof }\end{array}$ & $\begin{array}{l}\mathrm{BC} \\
\text { fos.f }\end{array}$ & $\begin{array}{l}\text { BC } \\
\text { all }\end{array}$ & $\begin{array}{l}\text { POM } \\
\text { wildf }\end{array}$ & $\begin{array}{l}\text { POM } \\
\text { biof }\end{array}$ & $\begin{array}{l}\text { POM } \\
\text { fosf }\end{array}$ & $\begin{array}{l}\text { POM } \\
\text { soa }\end{array}$ & $\begin{array}{l}\text { POM } \\
\text { all }\end{array}$ & $\begin{array}{l}\mathrm{SO}_{2} \\
\text { wildf }\end{array}$ & $\begin{array}{l}\mathrm{SO}_{2} \\
\text { v.ex }\end{array}$ & $\begin{array}{l}\mathrm{SO}_{2} \\
\text { v.co }\end{array}$ & $\begin{array}{l}\mathrm{SO}_{2} \\
\text { dom }\end{array}$ & $\begin{array}{l}\mathrm{SO}_{2} \\
\text { road }\end{array}$ & $\begin{array}{l}\mathrm{SO}_{2} \\
\text { pow }\end{array}$ & $\begin{array}{l}\mathrm{SO}_{2} \\
\text { off-r }\end{array}$ & $\begin{array}{l}\mathrm{SO}_{2} \\
\text { ship }\end{array}$ & $\begin{array}{l}\mathrm{SO}_{2} \\
\text { indu }\end{array}$ & $\begin{array}{l}\mathrm{SO}_{2} \\
\text { all }\end{array}$ \\
\hline CANADA & 0.04 & 0 & 0 & 0.04 & 0.85 & 0 & 0 & 0.69 & 1.54 & 0.07 & 0 & 0 & 0 & 0 & 0 & 0 & 0 & 0 & 0.07 \\
\hline USA & 0.00 & 0.01 & 0 & 0.02 & 0.06 & 0.06 & 0 & 1.23 & 1.35 & 0.01 & 0.22 & 1.01 & 0 & 0 & 0 & 0 & 0 & 0 & 1.24 \\
\hline C AMERICA & 0.01 & 0 & 0 & 0.01 & 0.15 & 0.01 & 0 & 0.62 & 0.78 & 0.01 & 0.23 & 2.24 & 0 & 0 & 0 & 0 & 0 & 0 & 2.49 \\
\hline S AMERICA & 0.23 & 0.01 & 0 & 0.24 & 2.57 & 0.03 & 0 & 6.58 & 9.17 & 0.28 & 0.47 & 4.76 & 0 & 0 & 0 & 0 & 0 & 0 & 5.51 \\
\hline N AFRICA & 0 & 0.01 & 0 & 0.01 & 0 & 0.02 & 0 & 0.03 & 0.06 & 0 & 0 & 0 & 0 & 0 & 0 & 0 & 0 & 0 & 0 \\
\hline W AFRICA & 0.22 & 0.04 & 0 & 0.27 & 2.39 & 0.11 & 0 & 2.53 & 5.03 & 0.32 & 0.02 & 0 & 0 & 0 & 0 & 0 & 0 & 0 & 0.34 \\
\hline E AFRICA & 0.08 & 0.04 & 0 & 0.12 & 0.88 & 0.11 & 0 & 0.7 & 1.68 & 0.12 & 0.17 & 0.02 & 0 & 0 & 0 & 0 & 0 & 0 & 0.31 \\
\hline S AFRICA & 0.20 & 0.03 & 0 & 0.22 & 2.05 & 0.07 & 0 & 0.94 & 3.06 & 0.29 & 0.03 & 0.02 & 0 & 0 & 0 & 0 & 0 & 0 & 0.34 \\
\hline OECD EU & 0.00 & 0.01 & 0 & 0.01 & 0.04 & 0.05 & 0 & 0.33 & 0.41 & 0 & 0.08 & 0 & 0.01 & 0 & 0 & 0 & 0 & 0 & 0.10 \\
\hline EAST EU & 0.00 & 0.01 & 0 & 0.01 & 0.01 & 0.03 & 0 & 0.08 & 0.12 & 0 & 0 & 0 & 0 & 0 & 0 & 0 & 0 & 0 & 0 \\
\hline F. USSR & 0.09 & 0.02 & 0 & 0.11 & 2.10 & 0.13 & 0 & 0.98 & 3.21 & 0.17 & 0.14 & 0 & 0 & 0 & 0 & 0 & 0 & 0 & 0.31 \\
\hline MID EAST & 0 & 0.01 & 0 & 0.01 & 0 & 0.02 & 0 & 0.12 & 0.15 & 0 & 0.03 & 0 & 0 & 0 & 0 & 0 & 0 & 0 & 0.03 \\
\hline SOUTH ASIA & 0.01 & 0.06 & 0 & 0.07 & 0.08 & 0.29 & 0 & 0.69 & 1.06 & 0.01 & 0 & 0 & 0.03 & 0 & 0 & 0 & 0 & 0 & 0.04 \\
\hline EAST ASIA & 0.01 & 0.10 & 0 & 0.10 & 0.10 & 0.46 & 0 & 0.69 & 1.26 & 0.01 & 0.02 & 0 & 0.05 & 0 & 0 & 0 & 0 & 0 & 0.08 \\
\hline SE ASIA & 0.06 & 0.03 & 0 & 0.10 & 0.74 & 0.13 & 0 & 1.49 & 2.36 & 0.06 & 0.44 & 0.79 & 0.01 & 0 & 0 & 0 & 0 & 0 & 1.30 \\
\hline OCEANIA & 0.06 & 0 & 0 & 0.07 & 0.78 & 0.01 & 0 & 0.97 & 1.77 & 0.10 & 0.11 & 4.52 & 0 & 0 & 0 & 0 & 0 & 0 & 4.72 \\
\hline JAPAN & 0 & 0.01 & 0 & 0.01 & 0.01 & 0.03 & 0 & 0.05 & 0.08 & 0 & 0.22 & 2.57 & 0 & 0 & 0 & 0 & 0 & 0 & 2.79 \\
\hline GREENLAND & 0 & 0 & 0 & 0 & 0 & 0 & 0 & 0 & 0 & 0 & 0 & 0 & 0 & 0 & 0 & 0 & 0 & 0 & 0 \\
\hline OCEAN & 0 & 0.07 & 0 & 0 & 0 & 0 & 0 & 0.4 & 0.40 & 0 & 1.83 & 9.29 & 0 & 0 & 0 & 0 & 0 & 0 & 11.1 \\
\hline WORLD & 1.03 & 0.39 & 0 & 1.41 & 12.8 & 1.56 & 0 & 19.1 & 33.5 & 1.46 & 4.00 & 25.2 & 0.12 & 0 & 0 & 0 & 0 & 0 & 30.8 \\
\hline
\end{tabular}

wildf - wildfire, biof - biofuel, fos.f - fossil fuel, v.ex - volcanic, explosive, v.co - volcanic, continuous, dom - domestic, road - road traffic, pow - powerplant, off-r - off road, ship - shipping, indu - industry

resulting in core aerosol (mainly $\mathrm{BC}$ and low volatility organics) of $\mathrm{r}_{\mathrm{m}}=0.32 \mu \mathrm{m}$ andg $\sigma=1.9$.

\section{Appendix D}

\section{Comparison of available wildland fire inventories}

By 2003, three different global large-scale wildland fire inventories had been developed (van der Werf et al., 2004; 


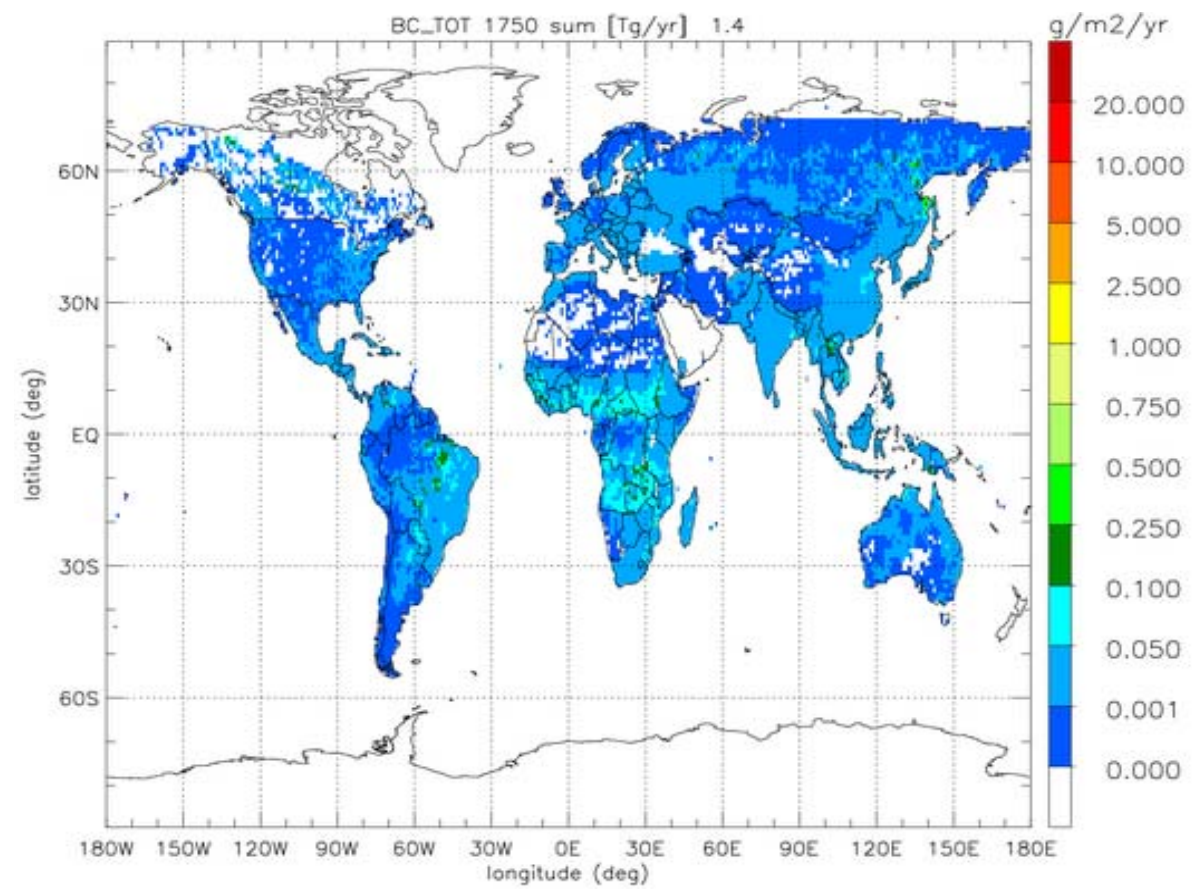

Fig. B5. Global distribution of all BC emissions for the year 1750.

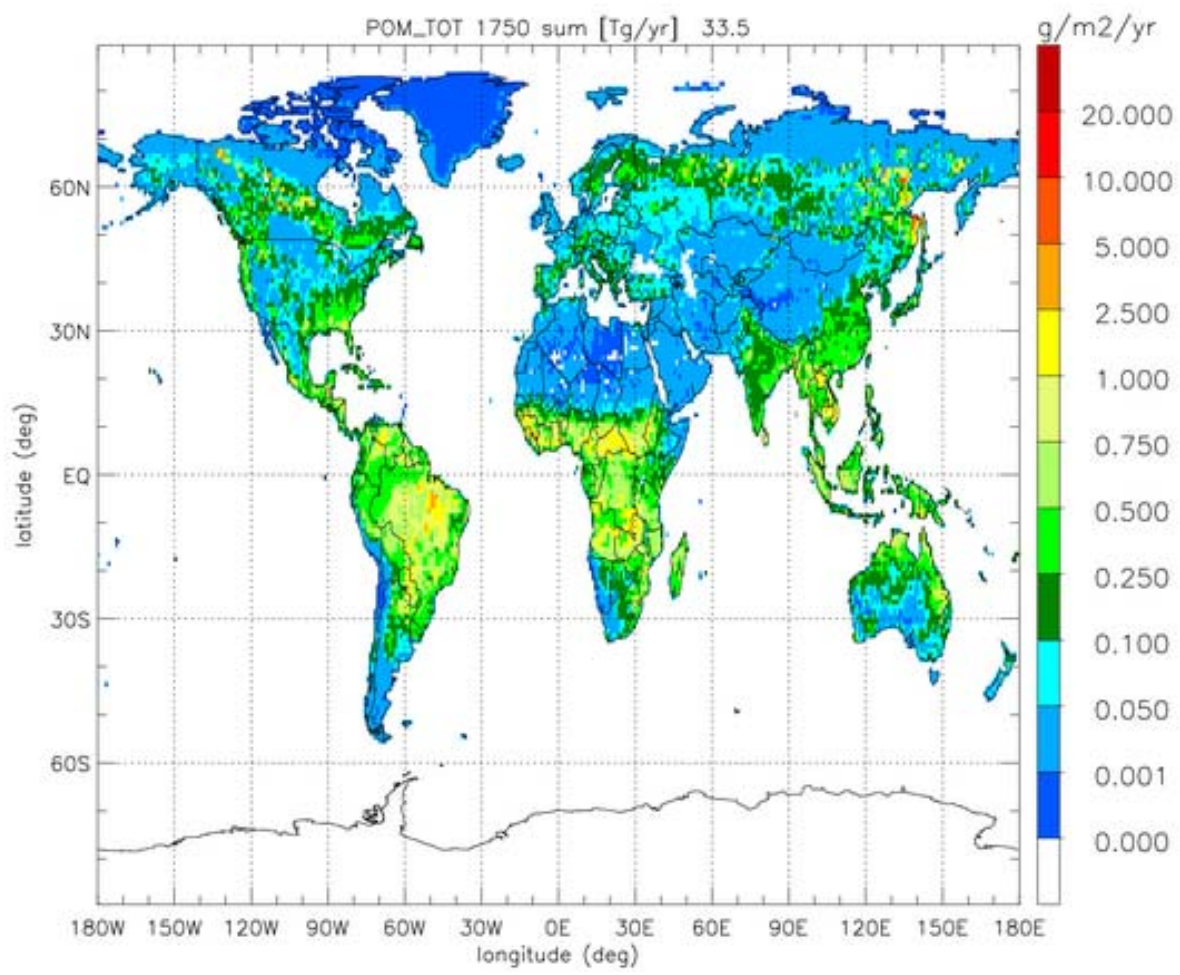

Fig. B6. Global distribution of all POM emissions for the year 1750 . 


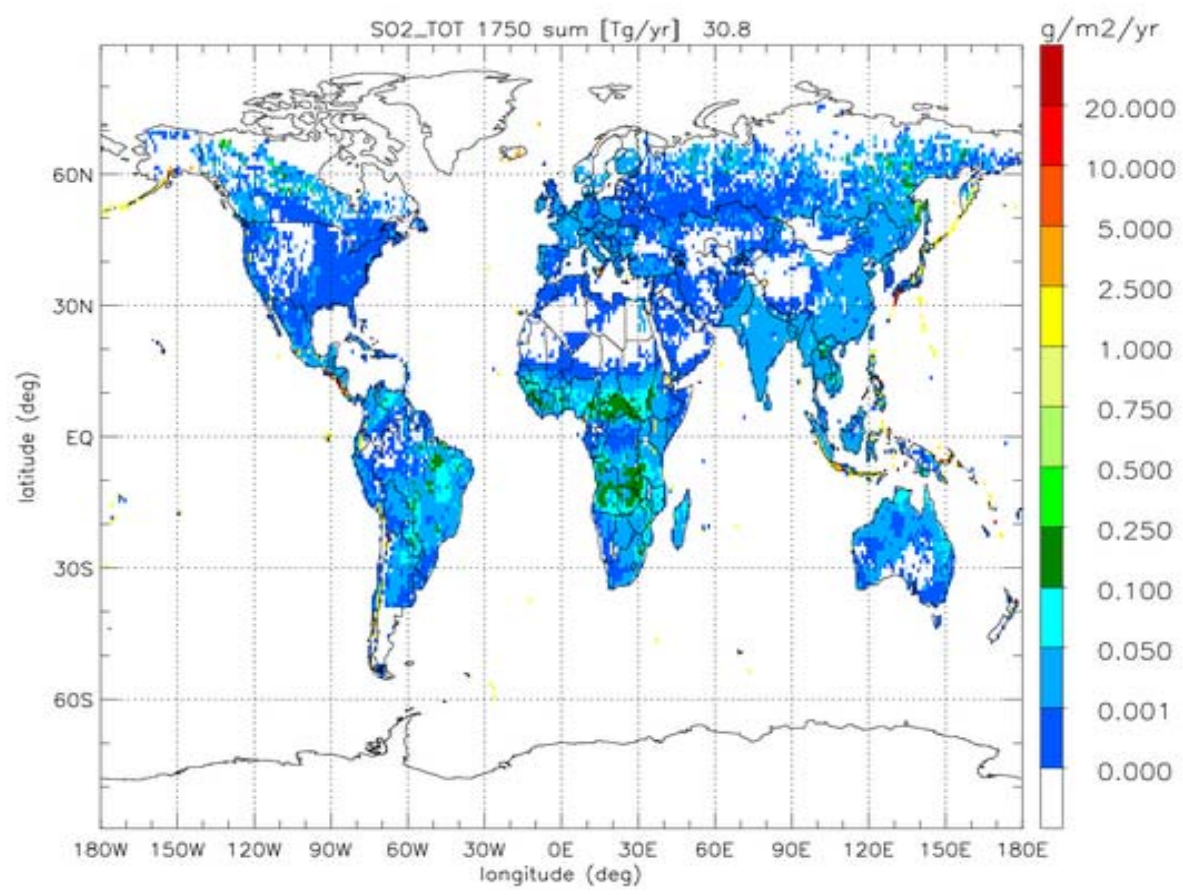

Fig. B7. Global distribution of all $\mathrm{SO}_{2}$ emissions for the year 1750 .

Table B3. Regional population for the year 1750 and population ratios for selected subsequent years with respect to the year 1750 population according to the HYDE database.

\begin{tabular}{|c|c|c|c|c|c|}
\hline & $\begin{array}{l}\text { yr } 1750 \\
\text { (in million) }\end{array}$ & $\begin{array}{l}1860 \text { / } 1750 \\
\text { pop - ratio }\end{array}$ & $\begin{array}{l}1890 / 1750 \\
\text { pop - ratio }\end{array}$ & $\begin{array}{l}1950 \text { / } 1750 \\
\text { pop - ratio }\end{array}$ & $\begin{array}{l}1990 / 1750 \\
\text { pop - ratio }\end{array}$ \\
\hline Canada & 0.3 & 7.6 & 23 & 46 & 93 \\
\hline USA & 2.1 & 11.5 & 46 & 75 & 121 \\
\hline C.America & 5.5 & 2.4 & 5.1 & 9.8 & 26 \\
\hline S.America & 5.0 & 3.6 & 9.8 & 22.5 & 59 \\
\hline N.Africa & 4.5 & 3.0 & 5.4 & 9.8 & 26 \\
\hline W-Africa & 22.1 & 1.7 & 2.3 & 3.9 & 11 \\
\hline E-Africa & 8.0 & 2.1 & 3.6 & 6.6 & 19 \\
\hline S-Africa & 10.7 & 1.6 & 2.3 & 3.9 & 11 \\
\hline OECD-Europe & 113.7 & 1.8 & 2.4 & 2.9 & 3.3 \\
\hline E-Europe & 31.6 & 1.2 & 2.4 & 2.8 & 3.9 \\
\hline F.USSR & 25.3 & 2.7 & 6.3 & 7.1 & 11 \\
\hline M-East & 9.3 & 1.6 & 3.7 & 6.3 & 21 \\
\hline S-Asia & 172.0 & 1.9 & 1.9 & 2.7 & 6.5 \\
\hline E-Asia & 268.9 & 1.6 & 1.6 & 2.7 & 4.6 \\
\hline SE-Asia & 28.5 & 1.6 & 3.5 & 6.4 & 16 \\
\hline Oceania & 0.3 & 1.8 & 22 & 42 & 88 \\
\hline Japan & 24.9 & 1.1 & 2.0 & 3.4 & 5.0 \\
\hline World & 722.3 & 1.8 & 2.4 & 3.5 & 7.3 \\
\hline
\end{tabular}




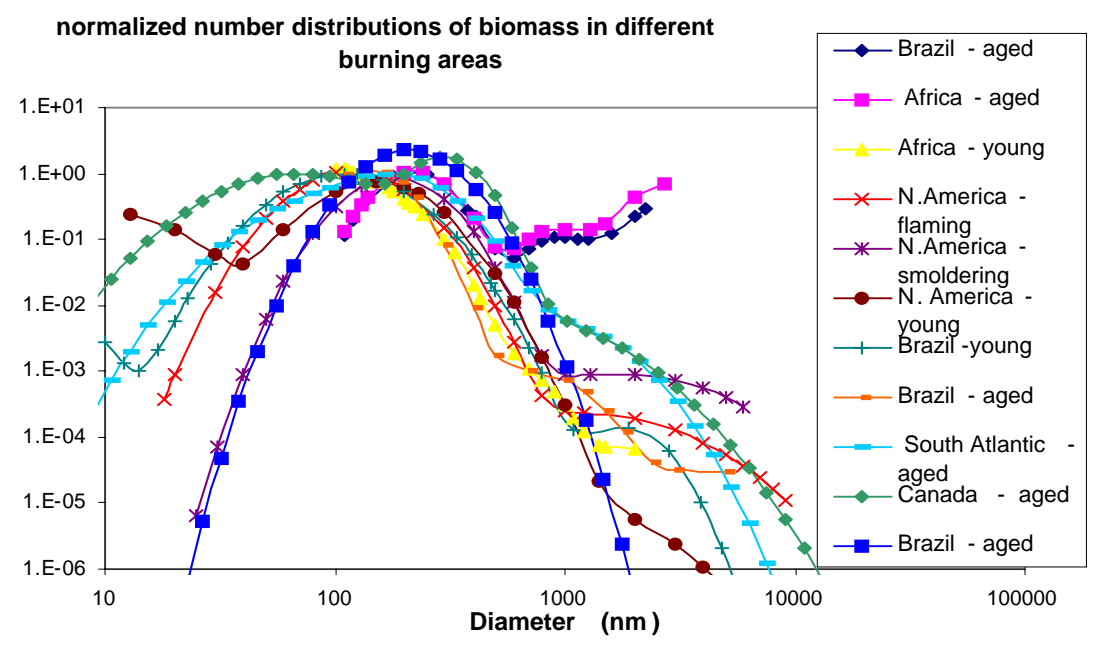

Fig. C1. Multi-modal log-normal fits to measured biomass size samples.

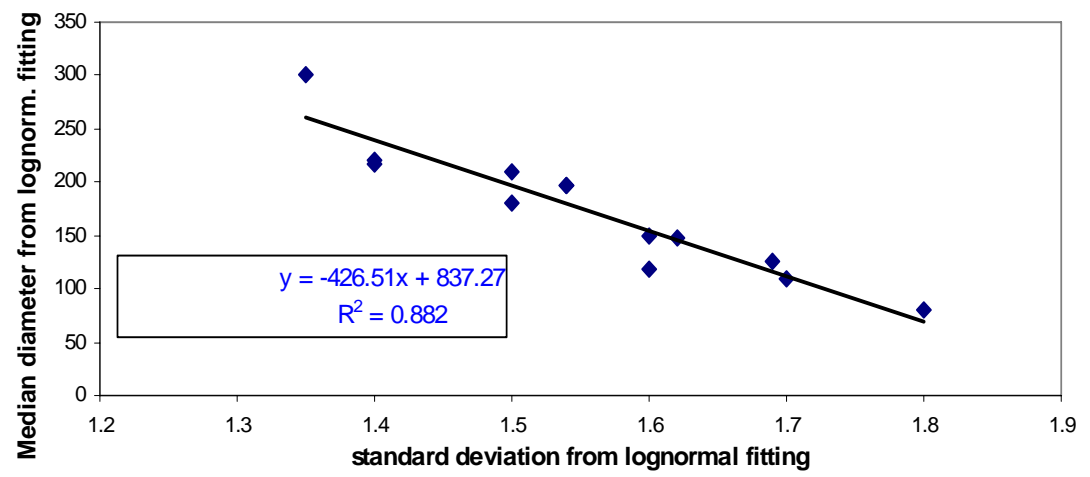

Fig. C2. Relationship between (number-) mode diameter (in $\mathrm{nm}$ ) and standard deviation (describing the distribution width) from log-normal fits to the size-distributions of Fig. C1. Data points in the lower right refer to young biomass aerosol. Data points towards the upper left refer to aged biomass aerosol indicating an aging trend to larger mode-radii and narrower distribution width.

\section{Comparisons of POM estimates}

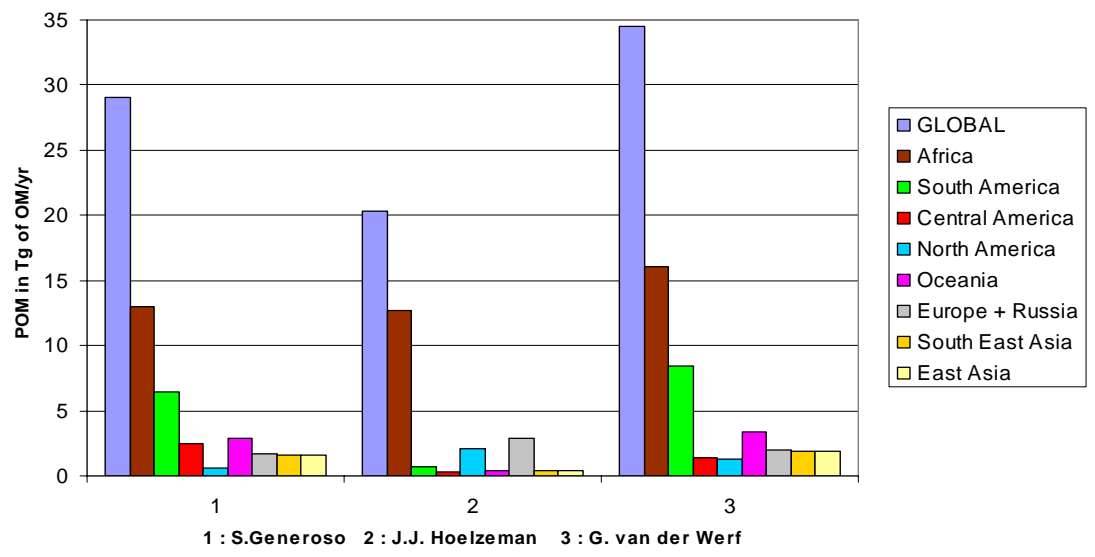

Fig. D1. Comparison of three different global large-scale burning (wildland fire) inventories for regional POM emission estimates by Generoso et al. (2003), Hoelzemann et al. (2004) and van der Werf et al. (2004). 
Generoso et al., 2003; Hoelzemann et al., 2004). When comparing the inventories on a regional basis, as for POM in Fig. D1, there is good agreement in a relative sense, although estimates by Hoelzemann (GWEM 1.2) are smaller, especially in South America. This lower estimate is erroneous and associated with a failure in the underlying area burnt satellite product, so that the impact of small but intense fires is underestimated in that region. A more recent version of GWEM (version 1.4) is now more consistent with the other inventories. For more discussion on the uncertainty of the POM/EC inventories, the reader is referred to the description of SPEW (Bond et al., 2004). A particular problem is the uncertainty of emission factors, which for $\mathrm{BC}$ can exceed an order of magnitude (C. Liousse, private communication, 2005). Thus, the certainty for carbonaceous emissions can not be expected to be better than a factor of 2 .

Acknowledgements. AeroCom was sponsored by the European Union FP5 project "Phoenics" EVK2-CT-2001-00098.

Edited by: A. Petzold

\section{References}

Allen, A. and Miguel, A.: Biomass burning in the Amazon: Characterisation of ionic component of the aerosols generated from flaming and smouldering rainforest and savannah, Environ. Sci. Tech., 29, 486-493, 1995.

Anderson, B., Grant W., Gregory, G., Browell, E., Collins Jr., J., Sachse, G., Hudgins, C., Blake, D., and Blake, N.: Aerosols from Biomass Burning Over the South Atlantic Region: Distributions and Impacts, J. Geophys. Res., 101, 24 117-24 138, 1996.

Andreae, M. and Merlet, P.: Emission of trace gases and aerosols from biomass burning, Global Biogeochemical Cycles, 15, 955966, 2001

Andres, R. and Kasgnoc, A.: A time-averaged inventory of subaerial volcanic sulfur emissions, J. Geophys. Res., 103, 19, 25 251-25 261, 1998.

Bond, T., Streets, D., Yarber, K., Nelson, S., Wo, J.-H., and Klimont, Z.: A technology-based global inventory of black and organic carbon emissions from combustion, J. Geophys. Res., 109, D14203, doi:10.1029/2003JD003697, 2004.

Boucher, O., Moulin, C., Belviso, S., Aumont, O., Bopp, L., Cosme, E., vonKuhlmann, R., Lawrence, M. G., Pham, M., Reddy, M. S., Sciare, J., and Venkataraman, C.: DMS atmospheric concentrations and sulphate aerosol indirect radiative forcing: a sensitivity study to the DMS source representation and oxidation, Atmos. Chem. Phys., 3, 49-65, 2003,

http://www.atmos-chem-phys.net/3/49/2003/.

Brenkert A., Marland, G., Boden, T., Andres, R. and Olivier, J.: CO2 emissions from fossil fuel burning: Comparisons of 1990 gridded maps and an update to 1995, EOS Transactions, AGU, 78, 111, 1997.

Brenkert, A. L., Auclair, A., Bedford, J. A., and Revenga, C.: Northern Hemisphere Biome and Process Specific Forest Area and Gross Merchantable Volumes: 1890-1990, Carbon Dioxide Information Analysis Centre (CDIAC), Oak Ridge, Tenn., 1997.
Cachier, H., Liousse, C., Pertuisot, M. H., Gaudichet, A., Echarlar, F., and Lacaux, J. P.: African fire particulate emissions and atmospheric influence. Biomass Burning and Global Change, edited by: Levine, J. S., MIT Press, Cambridge, MA, 1996.

Cofala, J., Amann, M., Klimont, Z., and Schöpp, W.: Scenarios of World Anthropogenic Emissions of $\mathrm{SO}_{2}, \mathrm{NO}_{x}$, and $\mathrm{CO}$ up to 2030, Internal report of the Transboundary Air Pollution Programme, International Institute for Applied Systems Analysis, Laxenburg, Austria, pp. 17, 2005.

Cofala, J., Amann, M., Gyarfas, F., Schöpp, W., Boudri, J., Hordijk, L., Kroeze, C., Li, J., Dai Lin, Panwar, T., and Gupta, S.: Costeffective Control of $\mathrm{SO}_{2}$ Emissions in Asia, Journal of Environmental Management 72, 149-161, 2004.

Cofala, J., Amann, M., and Klimont, Z.: Calculating Emission Control Scenarios and their Costs in the RAINS Model: Recent Experience and Future Needs. Pollution Atmosphérique, Numéro special Angers Workshop, Oct 2000, Paris, France, ISSN 0032 3632, 2000.

Cooke, W. F., Liousse, C., Cachier, H., and Feichter, J.: Construction of a $1 \times 1$ degree fossil fuel emission data set for carbonaceaous aerosol and implementation and radiative effect in ECHAM4 model, J. Geophys. Res., 104, 22 137-22 162, 1999.

De Meij, A., Krol, M., Dentener, F., Vignati, E., Cuvelier, C., and Thunis, P.: The sensitivity of aerosol in Europe to two different emission inventories and temporal distribution of emissions, Atmos. Chem. Phys. Discuss., 6, 3265-3319, 2006, http://www.atmos-chem-phys-discuss.net/6/3265/2006/.

Dentener, F., Stevenson, D., Cofala, J., Mechler, J., Amann, R., Bergamashi, P., Raes, F., and Derwent, R.: The impact of air pollutant and methane emission controls on tropospheric ozone and radiative forcing: CTM calculations, Atmos. Chem. Phys., 5, 1731-1755, 2005, http://www.atmos-chem-phys.net/5/1731/2005/.

Gong, S. L.: A parameterization of sea-salt aerosol source function for sub- and super- micron particles, Global Biogeochemical Cycles, 17(4), 1097, doi:1029/2003GB002079, 2003.

Ginoux, P., Chin, M., Tegen, I., Prospero, J. M., Holben, B., Duboviki, O., and Lin, S. J.: Sources and distributions of dust aerosols simulated with the GOCART model, J. Geophys. Res., 106, 20 255-20 274, 2001.

Ginoux, P., Prospero, J. M., Torres, O., and Chin, M.: Long-term simulation of global dust distribution with the GOCART model: Correlation with the North Atlantic Oscillation, Environ. Model, Software, doi:10.1016/S1364-8152(03)00114-2, 2003.

Generoso, S., Breon, F. M., Balkanski, Y., Boucher, O., and Schulz, M.: Improving the seasonal cycle and interannual variations of biomass burning aerosol sources, Atmos. Chem. Phys., 3, 12111222, 2003, http://www.atmos-chem-phys.net/3/1211/2003/.

Graf, H., Langmann, B., and Feichter, J.: The contribution of Earth degassing to the atmospheric sulfur budget, Chemical Geology, 147, 131-145, 1998.

Hänel, G.: The properties of atmospheric aerosol particles as functions of relative humidity at thermodynamic equilibrium with the surrounding moist air, Adv. Geophys. 19, 73-188, 1976.

Halmer, M., Schmincke, H., and Graf, H.: The annual volcanic gas input into the atmosphere, in particular into the stratosphere: A global data-set for the past 100 years, J. Volca. Geotherm. Res., 115, 511-528, 2002. 
Hoelzemann, J., Schultz, M., Brasseur, G., Granier, C., and Simon, M.: Global Wildland Fire Emission Model (GWEM): Evaluating the use of global area burnt satellite data, J. Geophys. Res., 109, No. D14, D14S04, doi.:10.1029/2003JD003666, 2004.

Ito, A. and Penner, J. E.: Historical emissions of carbonaceous aerosols from biomass and fossil fuel burning for the period 1870-2000, Global Biogeochem. Cycles, 19, GB2028, doi:10.1029/2004GB002374, 2005.

Kanakidou, M., Seinfeld, J., Pandis, S., Barnes, I., Dentener, F., Facchini, M. C., van Dingenen, R., Ervens, B., Nenes, A., Nielsen, C. J., Swietlicki, E., Putaud, J. P., Balkanski, Y., Fuzzi, S., Horth, J., Moortgat, G., Winterhalter, R., Myhre, C., Tsigaridis, K., Vignati, E., Stephanou, E., and Wilson, J.: Organic aerosol and climate modeling: a review. Atmos. Chem. Phys., 5, 1053-1123, 2005,

http://www.atmos-chem-phys.net/5/1053/2005/.

Kettle, A. J. and Andreae, M. O.: Flux of dimethylsulfide from the oceans: A comparison of updated data sets and flux models. J. Geophys. Res., 105, 26 793-26 808, 2000.

Kinne, S., Schulz, M., Textor, C., Guibert, S., Balkanski, Y., Bauer, S. E., Berntsen, T., Berglen, T., Boucher, O., Chin, M., Collins, W., Dentener, F., Diehl, T., Easter, R., Feichter, H., Fillmore, D., Ghan, S., Ginoux, P., Gong, S., Grini, A., Hendricks, J., Herzog, M., Horowitz, L., Huang, P., Isaksen, I., Iversen, T., Koch, D., Kirkevåg, A., Kloster, S., Krol, M., Kristjansson, E., Lauer, A., Lamarque, J. F., Lesins, G., Liu, X., Lohmann, U., Montanaro, V., Myhre, G., Penner, J. E., Pitari, G., Reddy, S., Seland, Ø., Stier, P., Takemura, T., and Tie, X.: An AeroCom initial assessment - optical properties in aerosol component modules of global models, Atmos. Chem. Phys. Discuss., 5, 8285-8330, 2005 ,

http://www.atmos-chem-phys-discuss.net/5/8285/2005/.

Klein-Goldewijk, C. and Battjes, J.: A hundred year (1890-1990) database for integrated environmental assessments (HYDE, version 1.1), Report no. 422514002, National Institute of Public Health and the Environment (RIVM), Bilthoven, Netherlands, 1997.

Le Canut, P., Andreae, M., Harris, G., Wienhold, F. and Zenker, T.: Airborne studies of emissions from savanna fires in southern Africa, 1, Aerosol emissions measured with a laser optical particle counter, J. Geophys. Res., 101, 23 615-23 630, 1996.

Luo, C., Mahowald, N., and del Corral, J.: Sensitivity study of meteorological parameters on mineral aerosol mobilization, transport, and distribution. J. Geophys. Res, 108, 4447, doi:10.1029/2003JD003483, 2003.

Nightingale, P., Malin, G., Law, C., Watson, A., Liss, P., Liddicoat, M., Boutin, J., and Upstill-Goddard, R.: In situ evaluation of airsea gas exchange parameterizations using novel conservative and volatile tracers, Glob. Biogeochem. Cycles, 14, 373-387, 2000.

Olivier, J., Berdowski, J., Peters, J., Bakker, J., Visschedijk, A., and Bloos, J.: Applications of EDGAR including a description of EDGAR V3.0: reference database with trend data for 1970-1995, NRP Report, 410200 051, RIVM, Bilthoven, The Netherlands, 2002.

Olivier, J. G. J. and Berdowski, J. J. M.: The Climate System, edited by: Berdowski, J., Guicherit, R., Heij, B. J., and Brookfield, V. T., A. A. Balkema, 33-78, 2001.

Olivier, J., van Aardenne, J., Dentener, F., Pagliari, V., Ganzewald, L., and Peters J.: Recent trends in global greenhouse gas emissions: regional trends 1970-2000 and spatial distributions of key sources in 2000. Env. Sc., 2, (203), 81-99, doi:10.1080/15693430500400345, 2005.

Olson, J. S., Watts, J. A., and Allison, L. J.: Major World Ecosystem Complexes Ranked by Carbon in Live Vegetation, Carbon Dioxide Information Center, Oak Ridge National Laboratory, Oak Ridge, Tennessee, 1985.

Pétron, G., Granier, C., Khattatov, B., Yudin, V., Lamarque, J.-F., Emmons, L., Gille, J., and Edwards, D. P.: Monthly CO surface sources inventory based on the 20002001 MOPITT satellite data, Geophys. Res. Lett., 31, L21107, doi:10.1029/2004GL020560, 2004.

Pham, M., Mueller, J. F., Brasseur, G., Granier, C., and Megie, C.: A three-dimensional study of the tropospheric sulfate cycle. J. Geophys. Res. 100, 16 445-16490, 1995.

Putaud, J., van Dingenen, R., Baltensberger, U., Brueggemann, E., Charron, A., Facchini, M.C., Desceari, S., Fuzzi, S., Gehrig, R., Hansson, H. C., Harrison, R., Jones, A., Laj, P., Lorbeer, G., Maenhaut, W., Mihalolpoulos, N., Mueller, K., Palmgren, F., Querol, X., Rodriguez, S., Schneider, J., Spindler, G., tenBrink, H., Tunved, P., Torseth, K., Weingartner, E., Wiedersohler, A., Waehlin, P., and Raes, F.: A European Aerosol Phenomenology, physical and chemical characteristics of particulate matter at kerbside, urban, rural, and background sites in Europe, Report EUR 20411 EN, European Commission, Ispra, Italy, http:/ccu.jrc.it/ccu/, 2002.

Putaud, J., Raes, F., van Dingenen, R., Brüggemann, E., Facchini, M. C., Decesari, S., Fuzzi, S., Gehrig, R., Hüglin, C., Laj, P., Lorbeer, G., Maenhaut, W., Mihalopoulos, N., Müller, K., Querol, X., Rodriguez, S., Schneider, J., Spindler, G., tenBrink, H., Torseth, K., and Wiedensohler, A.: A European aerosol phenomenology-2: chemical characteristics of particulate matter at kerbside, urban, rural and background sites in Europe, Atmos. Environ., 38, 2579-2595, 2004.

Radke, L., Hegg, D., Hobbs, P., Nance, J., Lyons, J., Laursen, K., Weiss, R., Riggan, P., and Ward, D.: Particulate and trace gas emissions from large biomass fires in North America, Global Biomass Burning: Atmospheric, Climatic and Biospheric Implications, edited by: Levine, J. S., MIT Press, Cambridge Mass., 209 - 224, 1991

Reid, E., Reid, J., Meier, M., Dunlap, M., Cliff, S., Broumas, A., Perry, K., and Maring, H.: Characterization of African dust transported to Puerto Rico by individual particle and size-segregated bulk analysis, J. Geophys. Res. 108, 8591, doi:10.1029/2002JD002935, 2003.

Reid, J., Westphal, D., Liu, M., Richardson, K., Justice, C., Prins, E., Descloitres, J., and Miller, S.: Detection, Modeling, Impacts of Biomass and Oil Fires, Battlespace Atmos. and Cloud Impacts on Military Oper, (BACIMO), Sept. 9-11, Monterey, CA, 3-11, 2003.

Scholes, R., Kendall, J., and Justice, C.: The quantity of biomass burned in southern Africa, J. Geophys. Res., 101, 23 667-23 676, 1996.

Schulz, M., Textor, C., Kinne, S., Guibert, S., Balkanski, Y., Bauer, S., Berntsen, T., Berglen, T., Boucher, O., Chin,M., Dentener, F., Diehl, T., Feichter, H., Fillmore, D., Ghan, S., Ginoux, P., Gong, S., Grini, A., Hendricks, J., Horowitz, L., Isaksen. I., Iversen, T., Kloster, S., Koch, D., Kirkevåg, A., Kristjansson, J. E., Krol, M., Lauer, A., Lamarque, J. F., Liu, X., Montanaro, V., Myhre, G., 
Penner, J., Pitari, G., Reddy, S., Seland, Ø., Stier, S., Takemura, $\mathrm{T}$., and Tie, X.: Radiative forcing by aerosols as derived from the AeroCom present-day and pre-industrial simulations, Atmos. Chem. Phys. Discuss., 6, 5095-5136, 2006,

http://www.atmos-chem-phys-discuss.net/6/5095/2006/.

Susott, R., Ward, D., Babbitt, R., and Latham, D.: The measurement of trace emissions and combustion characteristics for a mass fire, Global Biomass Burning: Atmospheric, Climatic and Biospheric Implications, edited by: Levine, J. S., MIT Press, Cambridge, Mass., 245-257, 1991.

Textor, C., Graf, H., Timmreck, C., and Robock, A.: Emissions from volcanoes. Emissions of Chemical Compounds and Aerosols in the Atmosphere, Kluwer, Dordrecht, The Netherlands, 269-303, 2004.

Textor, C., Schulz, M., Kinne, S., Guibert, S., Balkanski, Y., Bauer, S. E., Berntsen, T., Berglen, T., Boucher, O., Chin, M., Dentener, F., Diehl, T., Easter, R., Feichter, H., Fillmore, D., Ghan, S., Ginoux, P., Gong, S., Grini, A., Hendricks, J., Horowitz, L., Huang, P., Isaksen, I. Iversen, T., Kirkevåg, A., Kloster, S., Koch, D., Kristjansson, E., Krol, M., Lauer, A., Lamarque, J. F., Liu, X., Montanaro, V., Myhre, G., Penner, J., Pitari, G., Reddy, S., Seland, Ø., Stier, P., Takemura, T., and Tie, X.: Analysis and quantification of the diversities of aerosol life cycles within AeroCom, Atmos. Chem. Phys., 6, 1777-1813, 2006,

http://www.atmos-chem-phys.net/6/1777/2006/. van Aardenne, J., Dentener, F., Olivier, J., Klein-Goldewijk, C., and Lelieveld, J.: A 1 x 1 degree resolution dataset of historical anthropogenic trace gas emissions for the period 1890-1990, Global Biogeochemical Cycles, 15(4), 909-928, 2001.

van der Werf, G. R., Randerson, J. T, Collatz, G. C., and Giglio, L.: Carbon emissions from fires in tropical and subtropical ecosystems, Global Change Biology, 9(4), 547-562, 2003.

van der Werf, G. R., Randerson, J. T., Collatz, G. J., Giglio, L., Kasibhatla, P. S., Arellano, A. F., Olsen, S. C., and Kasischke, E. S.: Continental-scale partitioning of fire emissions during the 1997 to 2001 El Nino/La Nina period, Science, 303 (5654), 73 76, 2004.

van Dingenen R., Raes, F., Putaud, J., Baltensberger, U., Charron, A., Facchini, M. C., Decesari, S., Fuzzi, S., Gehrig, R., Hansson, H. C., Harrison, E., Hüglin, C., Jones, A., Laj, P., Lorbeer, G., Maenhaut, W., Palmgren, F., Querol, X., Rodriguez, S., Schneider, J., tenBrink, H., Tunved, P., Torseth, K., Wehner, B., Weingartner, E., Wiedensohler, A., and Wahlin, P.: A European aerosol phenomenology-1: Physical characteristics of particulate matter at kerbside, urban, rural and background sites in Europe, Atmospheric Environment, 38, 2561-2577, 2004.

Wilson, J., Cuvelier, C., and Raes, F.: A modeling study of global mixed aerosol fields. J. Geophys. Res., 106, 34 081-34 108, 2001. 